\title{
A Conseoüência Jurídica do Conflito Normativo entre a Lei Ordinária e a Lei Complementar Tributária
}

\author{
Rogério A. Fernandes de Carvalho
}

\section{INTRODUÇÃO}

O problema proposto não é mera formulação abstrata desprovida de aplicação prática, visto Que a Qualificação jurídica dos fenômenos de contradição entre fontes jurídicas ad Quire grande importância em face das respostas que o direito venha dar e dos resultados que venha a estabelecer. Além disso, tem sua relevância justificada na medida em Que há a ausência de estudos sistemáticos sobre o tema, sendo observável o seu rarefeito debate teórico explícito no direito público brasileiro. Com efeito, a contradição entre a lei complementar e a lei ordinária tem sido tratada na doutrina brasileira, majoritariamente, através de duas posições antípodas: uma Que nega e outra que afirma a existência de hierarquia entre ambas, recentemente, alimentada pelos amplos debates que culminou com a edição da Súmula no 276 do STJ. Entretanto, passou à margem de maiores especulações teóricas o fato de Que já existia ampla produção jurisprudencial do STI e do STF enfrentando a matéria, embora de forma não sistemática, e sem critérios precisos e uniformes para as várias hipóteses de ocorrência do conflito entre as duas espécies normativas. Esta é a contribuição Que este trabalho pretende, dentro de seus limites, oferecer.

O objeto do trabaho busca, ao traçar um panorama das várias teorias envolvidas, oferecer uma resposta ao problema formulado com vistas à racionalização do controle de validade dos atos normativos. Ao almejar estabelecer critérios identificáveis e controláveis para resolver o confronto entre duas espécies normativas fundamentais do sistema de processo legislativo brasileiro, tenta-se ofertar uma contribuição científica para dar cumprimento a um dos objetivos traçados pela ordem constitucional, Que é a segurança jurídica. Procurou-se fazer um corte metodológico, Quanto ao próprio objeto de estudo, Que não se preocupou em esgotar a amplitude da função da lei complementar no sistema tributário nacional, mas, principalmente, da lei complementar prevista e descrita no artigo \$46 da Constituição. Quanto às fontes de decisão jurisprudencial consultadas, foram eleitos os tribunais superiores - Supremo Tribunal Federal e Superior Tribunal de justiça. 
Primeiramente, far-se-á um balanço das teorias Que têm sido utilizadas pela doutrina para resolver, abstratamente, o problema, para em seguida averiguar como a jurisprudência dos dois principais tribunais superiores do país tem se posicionado e redefinido a natureza jurídica do conflito; num segundo momento, intentar-se-á delimitar o papel da teoria da hierarQuia em consonância com a função exercida pela lei complementar no sistema constitucional tributário nacional para, finalmente, ofertar uma proposta de sistematização das hipóteses de conflito entre as duas espécies normativas.

\section{QUAL A CONSEQÜÊNCIA JURÍDICA DO CONFLITO NORMATIVO ENTRE A LEI ORDINÁRIA E A LEI COMPLEMENTAR TRIBUTÁRIA? HIPÓTESES TEÓRICAS POSSIVEIS PARA A RESOLUÇÃO DO PROBLEMA FORMULADO E A POSIÇÃO DOS TRIBUNAIS SUPERIORES NA SUA REDEFINIÇÃO}

O primeiro passo para avançar no problema proposto é descrever um conceito operacional de lei complementar e, após, estabelecer sua inter-relação com as teorias que tratam do conflito formulado: a "teoria da hierarquia", a "teoria da invasão de competência legislativa" e a "teoria da inconstitucionalidade reflexa". A teoria da hierareuia é a mais empregada e a que está na origem dos debates para resolver o problema proposto, e a aceitação ou negação da hierareuia entre estas duas espécies normativas resulta em diferentes conseqüências atributivas ao conflito. A teoria da invasão de competência é uma espécie de protótipo de negação da hierareuia e a teoria da inconstitucionalidade reflexa não contende, diretamente, com estas duas formulaçōes teóricas, mas tem sua importância derivada de seu uso para solucionar o conflito.

\subsection{Posiçóes teóricas adotadas para a resolução do conflito normativo}

\subsection{Conceito de lei complementar}

Em sentido amplo todas as leis seriam complementares à Constituição, mas em sentido estrito, são aquelas submetidas ao regime jurídico inscrito no art. $59 \mathrm{c} / \mathrm{c}$ art. $69 \mathrm{da}$ Constituição. O regime jurídico-formal da lei complementar é o regime resultante de um processo legislativo vinculado a critérios constitucionais de direito materia/ ou substantivo(a matéria correspondente a uma parcela do campo global de competências legislativas distribuído segundo rígidos eseuemas constitucionais de repartição) e de direito forma/ ou adjetivo (o Quorum especial e qualificado). As leis complementares são entes legislativos reconhecíveis formal (votada por maioria absoluta, a teor do artigo 69 da Constituição) e materia/mente (tem por objetivo - conteúdo - a complementação da Constituição, ouer ajuntando-the normatividade, ouer operacionalizando-the os comandos, havendo leis complementares normativas e leis complementares de atuação constitucional). Em apertada síntese, lei 
complementar é o ato legislativo para o qual se exige o Quorum especial e qualificado previsto na Constituição, e, em relação ao seu obịeto, o legislador constituinte elegeu determinadas matérias Que estão submetidas a sua regulação formalmente espeć́fica. Em linhas gerais, não há, na doutrina jurídica brasileira, salvo honrosas exceções, relevante discrepância sobre o conceito ora esboçado.

A par de Que há a concepção genérica de Que todos os diplomas normativos assumem caráter complementar de dispositivos constitucionais, posto Que implementam normas constitucionais de eficácia contida ou limitada, lei complementar no direito constitucional brasileiro é aquela que dispondo sobre matéria, expressa ou implicitamente, prevista na redação constitucional (requisito material ou ontológico) está submetida ao Quorum Qualificado do art. 69 (requisito formal)'. As diferenças entre a lei complementar a ordinária são basicamente duas: uma material, uma vez Que só poderá ser objeto de lei complementar a matéria taxativamente prevista na Constituição, enquanto todas as demais matérias deverão ser objeto de lei ordinária²; outra formal, relacionada ao Quorum Qualificado para aprovação da lei complementar.

\subsubsection{Teoria da hierarquia e sua tipologia}

Para Borges (1975), o termo "hierarquia" só tem sentido juridicamente para significar Que uma norma é inferior a outra norma Quanto a segunda regule a forma de criação da primeira norma. Com inspiração em Kelsen, diz Borges;

O direito regula a sua própria criação, enquanto uma norma jurídica pode determinar a forma pela Qual outra norma jurídica é criada, assim como, em certa medida, o conteúdo desta última. Regular a sua própria criação, de modo Que uma norma apenas determine o processo mediante o Qual outra norma é produzida ou também, em medida variável, o conteúdo da norma a ser produzida, é uma particularidade do direito. [...| A norma jurídica é válida, então, porque foi criada na forma estabelecida por outra norma Que funciona como o seu fundamento ou razão de validade. Dado o caráter dinâmico do direito, uma norma jurídica somente é válida na medida em que é produzida

1 A razão de existência da lei complementar, para Moraes (2002), consubstancia-se no fato de o legișlador constituinte ter entendido Que determinadas matérias não deveriam ser regulamentadas na própria Constituiçăo, sob pena de engessamento de futuras alterações; ao mesıno tempo, porém, não poderiam comportar constantes alteraçōes por meio de um processo legistativo ordinário.

2 Há autores que defendem a possibilidade de que outras matérias, além daquelas explicitamente submetidas à reserva de lei complementar no texto constitucional, possam ser reguladas por esta espécie normativa, e.g., Machado (1996) e Carvalho (2003). Entretanto, como Fitho (2003), entendemos que a lei complementar só pode regular as matérias Que estão previstas taxativamente no texto constitucional, não deixando arbítrio ao legislador $[\ldots]$ porque as matérias sujeitas à reserva de lei complementar são matérias que o legislador constituinte Quis resguardar do tratamento pefas maiorias ocasionais, emprestando-the maior rigidez. 
pelo modo determinado por uma outra norma Que representa o seu fundamento imediato de validade. Para Kelsen, a relação entre a norma que regula a produção de outra e a norma assim regularmente produzida pode ser figurada por uma imagem espacial de supra-infra-ordenação ${ }^{3}$.

A norma determinante da criação de outra é superior a esta; a criada de acordo com a primeira, the é, ao contrário, inferior. A criação de uma norma - a de grau mais baixo - é determinada por outra - a de grau superior - cuja criação é, por sua vez, determinada por outra norma de grau mais alto ${ }^{4}$. Em outro trabahho, refere Borges (1973):

A relação de hierarquia supõe que uma norma retira a sua validez da conformidade com outra norma. A segunda norma constitui a razão da validez da primeira porque determina a sua criação. Diz-se então que a primeira é uma norma subordinada ou de grau inferior e, a segunda, uma norma subordinante ou de grau superior. A relação entre a norma subordinante e a norma subordinada, cuja criação é regulada pela norma subordinante, é uma relação de hierarQuia, consistente num vínculo de supra e subordinação. ${ }^{5}$

Adotando esse conceito relacional de hierarquia, ou seja, um conceito de relação entre normas jurídicas (relação de supra-subordinação), importa identificar sua tipologia em relação ao objeto desse estudo, isto é, classificar os diferentes tipos de posições teóricas assumidas pelos juristas Quanto ao tema do conflito entre lei complementar e lei ordinária.

Prima facie, há três posicionamentos teóricos identificáveis: a) há hierarquia necessária entre lei complementar e lei ordinária; b) não há hierarQuia em nenhuma hipótese; c) não há hierarquia necessária, mas pontual, nos casos em Que a própria Constituição determina. No campo do direito tributário. é Machado (1996) Quem faz, no debate contemporâneo ${ }^{6}$, a defesa mais enfática da existência necessária de hierarquia entre as duas espécies normativas, sendo a superioridade hierárquica das normas jurídicas em geral conferida pelo elemento

3 BORGES, Iosé Souto Maior. Lei Complementar Tributária. São Paulo: RT, 1975, p.81.

4 Para Kelsen, mesmo quando a norma de grau superior determina apenas o órgăo que deve criar a norma de grau inferior (e não o seu contcúdo), ou seja, Quando autoriza esse óngăo a determinar, dc acordo com scu próprio critério, o processo de criação da norma inferior e o seu conteúdo, a norma superior é "aplicada" na críaçăo da norma inferior. E, para ele, a norma superior ten que determinar Quando mienos o órgão incumbido da criaçâo da norma inferior. Fundamento de validade de uma norma é, połs, a norna reguladora de sua criação, op. cit., p. 82.

5 BORGES, losé Souto Maior. Eficácia e Hierarquia da Lei Complementar. Revista de Direito Público, São Paulo, n. 25, p. 93-103, 1973.

- A hierarouia da lei complementar em relação à lei ordinária já fora objeto de defesa de Pinto Ferreira; do "primeiro" Geraldo Atalíba (csboçada em sua obra "Lea Complementar na Constituição"), posição depois revista Quando da contundente crítica de losé Souto Maior Borges; de losé Afonso da Silva (na primeira edição de sua "Aplicabilìdade das Normas Constitucionais", em 1968), posição também atenuada e adaptada à teoria desenvolvida por Souto Maior Borges; de Nelson Sampaio, de Wilson Accioli, de Haroldo Valadão. 
formal $^{7}$ e não pelo elemento material, isto é, pelo conteúdo da norma. Por esta caracterização, a lei complementar teria superioridade hierárquica em relação à lei ordinária tanto Quando regulasse matéria Que the é atribuída pela Constituição (reunião dos requisitos formalQuorum Qualificado - e material- matéria reservada a regulação pela lei complementar) como Quando regulasse matéria não sujeita à reserva de lei complementar (presença tão somente do requisito formah). Diz Machado (1996):

Na verdade a lei complementar é espécie normativa superior à lei ordinária, independentemente, da matéria Que regula, e mesmo Que disponha sobre matéria a ela nâo reservada pela Constituição, não poderá ser revogada por lei ordinária. [...] não há na vigente Constituição Qualeuer norma [...] Que expressa ou implicitamente autorize a conclusão de Que a lei complementar somente pode cuidar das matérias a estas reservadas pela Constituiçâo. Existem é certo, dispositivos Que tornam determinadas matérias privativas de lei complementar, o que é coisa rigorosamente diverso. A existência de um campo de reserva de lei complementar, todavia, não Quer dizer Que não possa a lei complementar cuidar de outras matérias ${ }^{B}$.

Ferreira Filho (2003) entende a lei complementar no sistema constitucional brasileiro como um tertium genusinterposto, na hierarquia dos atos normativos, entre a lel ordinária (e os atos que têm a mesma força que esta) e a Constituição (e suas emendas), sendo que o fundamento para este entendimento é o da maior garantia de representatividade que foi emprestado a determinadas matérias pelo legislador constituinte. Nessa Qualidade de ato intercalar entre a Constituição e a lei ordinária a lei complementar não tem natureza de norma constitucional, mas é hierareuicamente superior à lei ordinária, como explica o referido constitucionalista:

[...] Da inserção da lei complementar entre a Constituição e a lei ordinária, decorrem conseQüências inexoráveis e óbvias. [...] a lei ordinária, a medida provisória e alei delegada estăo sujeitas à lei complementar. Em conseQüência disso, não prevalecem contra ela, sendo inválidas as normas que a contradisserem?.

${ }^{7}$ No mesmo sentido. DIFINI (2003): [...] Se o legislador optar pela lei complementar, com maiores exigências formais, esta não poderá ser modilicada ou revogada por lei ordinária, para a Qual as exigências formais săo menos rígidas, do Que decorre menor hierarquia legislativa.

\& MACHADO, Hugo de Brito. Posição Hierárquica da Lei Complementar. Revista Dialética de Direito Tributário, Săo Paulo, n. 14, p. 19-22, 1996.

- FERrEjRA FILHO, Manoel Gonçalves. Curso de Direito Constitucional. 30ª Ed. São Paulo: Saraiva, 2003. 371 p.; Do Processo Legislativo. $3^{3}$ Ed. São Paulo: Saraiva, 1995. 
Moraes ${ }^{10}$ (2002) também defende a tese de Que há hierarquia entre as duas espécies normativas, não aceitando as alegações correntes de Que ambas retiram seu fundamento de validade diretamente da Constituição, bem como possuem diferentes campos materiais de competência.

A posição contrária, bem explicada por Bastos (1999), é a negação de existência de QualQuer hierarQuia entre a lei complementar e a lei ordinária ", pois estas não se subordinam reciprocamente, porquanto versam sobre matérias distintas e buscam seus fundamentos de validade diretamente na Constituição. Não há hierarquia, como relação de supra e subordinaçăo existente entre determinadas normas, mas sim repartição de competências legislativas ${ }^{12}$ estabelecida na própria Constituição. A exigência de Quorum especial de votação para as leis complementares traduziria apenas a preocupação do constituinte em dificultar um pouco a mudança de certas matérias, por ele havidas por relevantes.

A hierarquia pressupõe a existência de um requisito básico, Qual sẹja, a existência de um campo material comum. Existe hierarquia toda vez que o ato subordinante delimita a área material de atuação do subordinado (hierarquia material) ou Quando estabelece o seu modo de produção (hierareuia formal); entretanto, a hierareuia pressupõe eue o ato subordinante e o ato subordinado estejam dentro do mesmo campo material. Não é que acontece com a lei complementar e a lei ordinária, Que possuem campos materiais diferentes de atuação, discriminados pelo texto constitucional através de esQuemas de repartição de competências legislativas. Não há relação de verticalidade (hierareuização ou subordinação) entre a lei complementar e a lei ordinária, mas de horizontalidade (coordenação), visto Que ambas retiram seu fundamento de validade diretamente da Constituição, e a lei ordinária não tem seu fundamento de validade na lei complementar, como disserta Bastos (1999):

As leis complementares não são dotadas da rigidez das normas constitucionais, nem são dotadas da flexibilidade das leis ordinárias. As leis complementares são justamente as leis Que dão aplicação e desenvolvem determinados

10 [...] Em relação ao primeiro argumento, devenos lembrar que todas as espécies normativas primárias retiram seu fundamento de validade da própria Conslituição Federal, inclusive as próprias Emendas Constitucionais, e nem por isso se diga que estariam no mesmo patamar hierárquico que as demais. O segundo argumento. tecnicamente corretíssimo, corresponde a uma das diferenças entre lel complementar e lei ordinária. Enquanto a primeira tem reservadas as matérias pelas quais poderá ser editada, a segunda possui um campo residual de competência. Ocorre que o Direito como ciência năo é estanque, e determinada matéria reservada à lei complementar poderá possuir tantas subdivisões, que em uma delas poderá acabar confundindose com outra matéria residual a ser disciplina por lei ordinária.

"Posição também defendida por Michel Temer, pelo "segundo" Geraldo Ataliba (reviu sua posição após crítica de Souto Maior Borges), por André Ramos Tavares, por Moreira Alves.

12 Os campos da lei complementar e da lei ordinária, em princípio, năo se interpenetram, numa decorrência da técnica constitucional de distribuição ratione materiae de competências legislativas. Não se coloca o problema da revogação Quando se está em campos legislativos distintos: se a lei ordinária invadir o campo material da lei complementar será inválida (teoria da invasăo de competência legisfativa), independente de revogação; se a lei complementar invadir o campo material da lei ordinária terá validade de lei ordinária.. 
dispositivos constitucionais. Todavia, isso não implica em nenhuma hierarquia em relação às demais leis não complementares. Vale dizer mais uma vez Que na hierarquia o ente hierarquizado extrai a sua existência do ser hirarquizante, pelo Que, não há Que se falar, propriamente, em compatibilizaçāo, visto Que a espécie inferior só encontra validade nos limites traçados pela superior. Na hipótese de normas do mesmo nível, mas com matérias próprias, pode darse este vínculo de não contradição Que, insistamos, independe de pressuporse uma necessária inferioridade. Pelo contrário, exatamente por serem do mesmo nível é que têm de se coordenar ${ }^{13}$.

O terceiro posicionamento teórico é o de Que não há hierarquia necessária entre as duas espécies normativas, mas tão somente naQueles casos pré-determinados pela Constituição, em Que a lei complementar for o fundamento de validade da lei ordinária. Esta é a posição de Borges (1975), cujos clássicos estudos publicados em 1973 e 1975 serviram como divisor de águas sobre o tema. Borges (1973) enfoca a Questão a partir da análise do conteúdo do princípio de isonomia das pessoas constitucionais. Nessa perspectiva, não há hierarouia ou subordinação, do ponto de vista jurídico, entre as pessoas constitucionais (União, Estados-membros, Municípios e Distrito Federal), visto Que estas têm existência Fundada diretamente na Constituição. A técnica constitucional brasileira adotou o expediente de repartir, por campos privativos, as competências legislativas destes. Tem-se, portanto, Que a competência legislativa está repartida em compartimentos estaneues, representados pelos campos privativos de legislação da União, dos Estados-membros e dos Municípios. E como os poderes legislativos das pessoas constitucionais extraem sua competência diretamente da Constituição, suas respectivas leis não estão em relação de hierarquia umas com as outras, mas cada qual possui um campo de competência constitucionalmente delimitado e repartido. A partir dessa premissa, e, como todas as leis complementares estão submetidas ao mesno regime jurídico formal, a lei complementar, em relação ao seu regime jurídico material, não é categoria legislativa unitária, embora disciplinada pela Constituição em caráter uniforme ${ }^{14}$. Resta indagar se a lei complementar funciona como o fundamento de validade das leis ordinárias (e, eventualmente, de outros atos legislativos) federais, estaduais e municipais, na Qual Borges (1975) faz a seguinte classificação:

[...] Essa análise revelará dois grupos básicos de leis complementares: 10) leis complementares que fundamentam a validade de atos normativos (leis ordinárias, decretos legislativos e convênios); $2^{\circ}$ ) leis complementares Que não fundamentam a validade de outros atos normativos.

13 BASTOS, Celso. A Inexistência de Hierarouia entre a Lei Complementar e as Leis Ordinárias. Cadernos de Direito Tributário e Finanças Públicas, Săo Paulo, n. 26, p. 10-20, 1999.

${ }^{4}$ Embora Borges utilize o texto da Constituiçäo de 1969 para construir seu argumento, o raciocínio permanece válido para o regime jurídico da lei complementar sob a Constituiçăo de 1988. 
Em relação à matéria tributária, Borges (1975) identifica diversas hipóteses prescritivas de leis complementares Que fundamentam a validade de outros atos normativos (leis ordinárias, decretos legisiativos e convênios), entre os quais o das normas gerais de direito tributário:

Art. I 8 - (omissis)

$\S 1^{\circ}$ - Lei complementar estabelecerá normas gerais de direito tributário, disporá sobre os conflitos de competência nessa matéria entre a União, os Estados, o Distrito Federal e os Municípios e regulará as limitações constitucionais ao poder de tributar ${ }^{15}$.

Carvalho (2003) entende, com Souto Maior Borges, Que não há um perfil unitário para as leis complementares, visto que há aquelas que fundamentam a validade de outros atos normativos e aquelas Que não o fazem, como mostra o seguinte trecho:

Há a hierarquia sintática, de cunho eminentemente lógico, assim como há a hierarquia semântica, que, se biparte em hierarquia formal e hierarquia material. $\{\ldots\}$ A primeira, Quando a norma superior dita apenas os pressupostos de forma que a norma subordinada há de respeitar; a segunda, sempre Que a regra subordinante preceituar os conteúdos de significaçảo da norma inferior. ${ }^{16}$.

Nesse esquema analítico, há normas introduzidas por lei ordinária dos entes tributantes (norma subordinada) Que deverão procurar o âmbito de validade material de seu conteúdo prescritivo em normas de legislação complementar (norma subordinante), cujo exemplo está nas regras do art. 146 Que dispõem sobre conflitos de competência ${ }^{17}$.

Trata-se [...] de hipótese de hierarquia material, em que a regra veiculada por lei complementar submete suas inferiores hierárquicas: as introduzidas por lei ordinária $[\ldots]^{18 * 1}$. No mesmo sentido, Ávila ${ }^{19}$ :

As leis ordinárias situam-se, em dois casos, numa relação de hierarquia com as leis complementares: numa relação de hierarquia formal-procedimental, na hipótese de a lei complementar regular o modo de elaboração, redação, modificação e consolidação das leis ordinárias (art. 59); e numa relação de

15 Atos normativos cuja validade dependem de lei complementar: leis ordinárias federal (arts. 18, $\S 5^{\circ}, 21$ e 22), estadual (art. 23) e municipal (art. 24). Também, o $23, \S 6^{\circ}$ (isenção heterônoma do (CM): ato normativo cuja validade depende de lei complementar: convênio e decreto icgislativo de tatificaçäo do convênio.

is CARVAlHO, Paulo de Barros. Curso de Diretto Tributário. 15ª Ed. São Paulo: Saraiva, 2003.

17 Em relação à hierarquia formal, a Constituição de 1988 trouxe inovação prevista no art. 59, Que prevê lei complementar para dispor sobre a claboração, redação, alteraçâo e consolidaçăo das leis.

18 ldem, ibidem, p. 208.

19 ÁVII.A, Humberto. Sistema Constitucional Tributário. Săo Pauto: Saraiva, 2004. 
hierarquia material-conteudística, no caso de a lei complementar estabelecer normas gerais predeterminadoras do conteúdo das leis ordinárias instituidoras de tributos (art. 146) ${ }^{20}$.

\subsubsection{Teoria da invasâo de competência legislativa}

O sistema jurídico tem imputado a cominação ou do vício de inconstitucionalidade ou do vício de ilegalidade como conseqüência do confronto da lei ordinária com a lei complementar. A rigor, a temática tem sido tratada de forma tangencial pela doutrina, havendo carência de estudos sistemáticos. As posições teóricas dos autores nacionais, em sua maioria defensores de que haveria o vício de inconstitucionalidade. inter-relacionam-o com as teorias da "hierarquia" e da "invasäo de competência legislativa".

Bastos (1999) divide as leis complementares em duas espécies: a) leis complementares exaurientes. são aquelas que incidem de maneira direta sobre os fatos ou comportamentos reguladores, não necessitando de QualQuer normatização complementar. possuindo plena eficácia; corresponderia àquelas leis que não fundamentam a validade de outros atos normativos, na tipologia de Souto Maior Borges; b) less complementares continuáveis. são aquelas que permitem a existência de outras espécies normativas, que the intermediam a eficácia; corresponderia àquelas leis que fundamentam a validade de outros atos normativos, na tipologia de Souto Maior Borges. Entretanto, para Bastos (1999), há absoluta autonomia entre a lei complementar e a lei ordinária, no sentido de que, esta última, em absoluto, extrai o seu fundamento de validade da primeira, no que discorda de Souto.

O Que haveria seria necessária correlação de harmonia entre estas espécies normativas. Não há Que se confundir uma relação de compatibilização harmônica, Que pode existir entre normas do mesmo nível, com uma relação de subordinação, visto Que na relação de hierarquia o ente subordinado extrai a sua existência do ente subordinante, o Que não ocorreria entre a lei complementar e a lei ordinária. As leis complementares exaurientes não suscitam QualQuer problema em relação a sua precedência ou posterioridade cronológicas relativamente à lei ordinária, pois são normas voltadas a puro ato de execução. As leis complementares continuáveis, no entanto, suscitam este problema e são classificadas em duas espécies com conseQüências particulares: I) lei complementares que são pré-requisito indispensável à edição da lei ordinária: II) leis complementares Que não se constituem em pré-requisito à edição de lei afim. No primeiro caso, diz Bastos (1999):

20 Idem, ibidem, p.133: [...] pode a lei ordinária revogar uma lei complementar? Se houver hierarquia necessária entre as fontes, não. Se não houver e for um caso em que inexiste a hierarquia, sim. [...] seguese o entendimento no sentido de que não há hierarquia necessária entre a lei complementar e a lej ordinária. A hierarquia é eventual, existente no caso de a lei complementar exercer uma função fundante da lei ordinária. Mas não sendo esse o caso, se o legislador escolheu a lei complementar como instrumento para regular determinada situação de fato sem Que a Constituiçăo o exigisse, na verdade a lei complementar exerce função de lei ordinária [...]. 
a) se a lei complementar existe e a lei ordinária com ela conflita temos que a lei ordinária é inconstitucional, porque aquela matéria foi reservada pela Constituição à Lei Complementar; b) se a lei complementar não existe e a lei ordinária é editada, esta também será inconstitucional, poreue contraria frontalmente a Constituição uma vez que esta prevê para regular tal matéria a edição de uma lei complementar, e não de uma lei ordinária ${ }^{2 !}$.

No segundo caso, prossegue o autor:

a) a lei complementar existe e a lei ordinária com ela conflita, estamos diante da inconstitucionalidade desta última; b) a lei complementar não existe quando da edição de lei ordinária, mas Quando pós editada configura uma inadeQuação, estamos diante de um caso de cessão de efícácia da lei ordinária ${ }^{22}$.

$\operatorname{Bastos}^{23}(2001)$, partindo da premissa que inexiste hierarquia entre elas, entende Que a hipótese de colisão da lei ordinária editada após a complementar implica na inconstitucionalidade daQuela, pois haveria invasão de competência da lei ordinária no campo normal de atuação da lei complementar designado no texto constitucional. Silva (2003), seguindo a doutrina de Souto Maior Borges, entende que há relação hierárquica entre a lei complementar e a lei ordinária, Quando aquela for o fundamento de validade desta. E se do confronto entre a lei ordinária e a lei complementar que lhe empresta fundamento de validade ocorre vício de ilegalidade ou inconstitucionalidade é por Silva (2003) assim tratada:

A lei ordinária eue ofender a lei complementar é ilegal, ou inconstitucional? [...] se não houver ainda lei complementar regulando a matéria mesmo nesse caso, termos simplesmente uma invasão de competência, Que se resolve pelo confronto entre a lei ordinária (ou outro ato) e a própria Constituição. A Questão da ofensa à lei complementar, evidentemente, só se coloca se esta já existir e for de natureza normativa, ou seja, fundante da validade de outros atos normativos, como a do art. 146 (Código Tributário Nacional). [...] Dizer Que se trata de mera ilegalidade não só repugna considerar uma lei ilegal, como teríamos um modo de invalidar lei, Que goza de presunção constitucional de validade, sem a observância de regras de controle de constitucionalidade $[\ldots]^{24}$.

2t BASTOS, Celso. Lei Complementar - Teorta e Comentários. Săo Paulo: Celso Bastos Editor, 1999. p. 106.

2. Idem, ibidem, p. 110

¿3 [... a hipótese consistente em urna lei ordinária ser seguida por uma lei complementar continuável. Essa hipótese comporta uma dúplice soluçẫo conforme estejamos diante de um dos dois seguintes casos. No primeiro, a leí ordinária poderia ter sido editada mesmo sem a complementar. [...] O que se dá no caso em exame é uma verdadeira perda de eficácia equiparável, se bem que não idêntica, à revogação. $|\ldots|$ o o segundo caso, Qual seja, o de a lel complementar ser pré-requisito indispensável para a edição da lei ordinária. Aqui a solução se nos afigura muito simples. Trata-se de pura e manifesta inconstitucionalidade. BASTOS, Cejso. Do Estudo da Inconstitucionalidade no Campo Específico da Lei Complementar. Revista de Direito Constitucional e Internacional, São Paulo, n. 37. p. 55-63, 2001.

${ }^{24}$ SILVA, José Afonso. Aplicabilidade das Normas Constitucionais. Ga Ed. Săo Paulo: Malheiros, 2003. 277 p. 
Silva (2003) cria a alcunha ilegitimidade constitucionalpara esses casos, emprestada da doutrina italiana, asseverando Que o controle de ilegitimidade constitucional atenderia aos mesmos princípios do controle de inconstitucionalidade, nos seguintes termos:

Com efeito, lei ordinária Que ofenda uma lei complementar estará vulnerando a própria Constituição, visto Que disciplinará interesses Que esta determina sejam regulados por ela. Tratar-se-á, então, de conflito de normas, subordinado ao princípio da compatibilidade vertical, entroncando, pois, na norma de maior superioridade hierárquica, Que é a Que ficou ofendida - a Constituição. Pronunciamo-nos, destarte, pelo controle de constitucionalidade das leis, com todas as suas conseqüências, Quando uma regra jurídica ordinária conflite com uma complementar ${ }^{25}$. (grifo nosso).

A premissa defendida por Poletti (2001) é de que há hierarquia entre as leis complementares e as ordinárias, com prevalência da primeira sobre a segunda; no entanto, entende que a idéia de hierarquia não se coaduna com a tese de que haveria ilegalidade no confronto entre essas duas espécies normativas:

[...] A solução está na tese da inconstitucionalidade, embora isso deva ser explicado. Se uma lei ordinária dispóe contrariamente a uma lei complementar deve ser declarada inconstitucional. As leis complementares contêm matéria constitucional do ponto de vista formal, embora do prisma material possa ocorrer, como acontece no próprio texto constitucional, trate do assunto em relação ao Qual a Constituição a ela não cometera. Isto parece, todavia, não afastar, como não afasta em relação à Constituição, a declaração de inconstitucionalidade. ${ }^{26}$

A fundamentação do autor é baseada em julgados do Supremo Tribunal Federal que trataram do tema ${ }^{27}$, principalmente, no Recurso Extraordinário $n^{\circ} 84.994^{28}$, onde se discutiu

25 Idem, ibidem, p. 277.

zo POLETTI, Ronaldo. Controle da Constitucionalidade das Leis. $2^{\mathrm{a}}$ Ed. Rio de lanciro: Forense, 200 I . b

${ }^{27}$ O Ministro Alfredo Buzaid entendeu que "Violação de lei complementar para efeito de recurso extraordinário se equipara à lei ordinária, não sendo, portanto, o mesmo Que ofensa à Constituição". RT) 103-1.062.

28 No referido recurso, excertos do debate travado entre os Ministros Leitão de Abreu e Moreira Alves revelam o teor da controvérsia das duas teorias en confronto: O Sr Ministro Leitão de Abreu - A questão, no caso, se resolve $\mathrm{em}$ face da hierarquia das leis. Havendo conflito de norma colocado em grau hierárquico inferior com norma hiesarquicamente superior, esta prevalece, acarretando a invalidade da primeira. $[\ldots] \mathrm{O} \mathrm{Sr}$. Ministro Moreira Alves - Mcsmo Que fossc problema de hierarquia se uma lei inferior invadisse a competência de lei superior seria inconstitucional. O Sr. Ministro Leitão de Abreu - É ilegal. O Sr. Ministro Moreira Alves - Decreto-lei que invade atribuição reservada à área de competência de lel ordinária, Que está no mesmo plano hierároụico, é inconstitucional, sem qualquer dúvida. Se invadisse a esfera de competência de legislação complementar, que V. Exa. considera superior hierarquicamente. O Sr. Ministro Leitão de Abreu - A inferior será ilegal, não inconstitucional, o que acontecerá quando entrar $\mathrm{em}$ conflito com a Constituição. [...] A lei ordinária entrou em choque com a lei hierarouicamente superior, isto é, lei complementar, tornando-se, por îsso, inválida, năo inconstitucional, pois isto só ocorre Quando contraria a Constituição. O Sr. Ministro Moreira Alves - O problema é sempre de invasão de competência, c a conseqüência a mesma: a inconstitucionalidade. 
o problema da ilegalidade ou inconstitucionalidade, com o enfoque em duas teorias: a teoria da hierar quia e a da invasão de competência legislativa.

Barroso (2004) converge Quanto à natureza do vício (de inconstitucionalidade) atribuível ao confronto, mas entende que não há uma relação de hierarquia, mas de competência:

Não há entre ela e a lei ordinária uma relação de hierarquia, senão Que de competência. Logo, não é possível controlar uma lei ordinária em face de uma complementar. Mas, se a lei ordinária dispuser de tema assinalado à lei complementar, incidirá em inconstitucionalidade, por violar a demarcação de competência de uma e de outra instituída na Constituição ${ }^{29}$.

Paulsen (2005), ao explicar seu posicionamento contrário às reiteradas decisóes do Superior Tribunal de Justiça que tem entendido que o "confronto entre lei ordinária e lei complementar não é matéria constitucional, porque o princípio da hierarquia das leis está inserido na Lei de Introdução ao Código Civil" expõe:

Trata-se, sim, de questão constitucional, a ser dirimida pelo STF. Inexiste juízo de "ilegalidade complementar" no sentido de analisar a adeQuação de lei ordinária à lei complementar, sendo o caso, sempre, se saber se houve invasão de matéria reservada constitucionalmente à lei complementar e, portanto, matéria constitucional ${ }^{30}$.

\subsubsection{Teoria da inconstitucionalidade reflexa ou indireta}

Posição contrária à precedente é oferecida por Miranda (2002), para Quem há ciara diferenciação entre a legalidade e a constitucionalidade, sendo a primeira a relação de conformidade entre um ato normativo com a lei ordinária (ou com o Direito Ordinário), e a segunda a relação de conformidade com a Constituição; negativamente, têm-se as noções de ilegalidade e inconstitucionalidade. A diferença entre os dois conceitos não é de natureza jurídica, mas se dá pela Qualidade dos preceitos ofendidos, ou seja, o parâmetro de controle é Que diferencia a conceituação: se o parâmetro ofendido é a lei ordinária, tem-se a ilegalidade; se a Constituição tem-se a inconstitucionalidade. Diz o autor português:

A distinção radica na norma Que disciplina o acto de que se trate, fixando-lhe pressupostos, elementos, requisitos (de Qualificação, validade e regularidade). Se fora a Constituição; o acto será inconstitucional em caso de desconformidade; se tais requisitos não se encontrarem senão na lei, já a sua falta torná-lo-á meramente ilega $\left.\right|^{3 !}$.

29 BARROSO Luis Roberto. O Controle de Constitucionalidade no Direito Brasileiro. São Pauto: Saraiva, 2004.

30. PAUSEL, Leandro. Direito Tributário. Constituição e Código Tributário à luz da Doutrina e da Jurisprudência. $7^{\text {a }}$ Ed. Porto Alegre: Do Advogado, 2005.

3 MIRANDA, Jorge. Teoria do Estado e da Constituiçäo. Rio de Janeiro: Forense, 2002, 546 p.. 
Embora a Constituição seja o fundamento de toda a ordem jurídica, a Qual todo o direito ordinário está submetido, não podendo contrariá-la nem opor-se a seus comandos, disto não decorre que qualquer desarmonia se traduza em inconstitucionalidade. Prossegue Miranda (2002):

O problema complica-se em alguns casos: Quando a Constituição prescreve (ou Quando é a Constituição a prescrever) a subordinação de um acto a um norma infraconstitucional e Quando, portanto, uma infracção dessa norma Que parece interposta - vem a redundar em violação da Constituição. [...] Reiteramos a opinião que há muito sustentamos de Que se trata de um problema de ilegalidade (ou de ilegalidade sui generis), e não de inconstitucionalidade. E isso não somente por virtude do próprio teor do fenômeno: pois o Que está em causa em Qualquer das hipóteses é. primariamente, a contradiçăo entre duas normas não constitucionais, não é a contradição entre uma norma ordinária e uma norma constitucional; e é somente por se dar tal contradição Que indirectamente (ou, porventura, conseeüentemente) se acaba por aludir a inconstitucionalidade. Por outras palavras: a distinção encontra-se Quer numa perspectiva de fundamentação ou condiçãa de validade [... Quer num critério prático de confronto entre a norma que seja argüida de desconformidade e a norma Que, directa e imediatamente, recai sobre o seu objecto e que deve ter-se por seu parâmetro ${ }^{32}$.

Síntese desse posicionamento é que a invalidade dos atos jurídicos não se esgota sempre em inconstitucionalidade. Isto se explica, também, porque o sistema jurídico não está organizado de forma circular, mas hierareuizada ${ }^{33}$. Interessante construção teórica aplicável ao problema proposto é a teoria da inconstitucionalidade reflexa ou indireta. O problema da inconstitucionalidade das leis resulta de uma relação imediata de incompatibilidade com a Constituição. Esta a idéia chave para se compreender a definição de inconstitucionalidade obliqua ou reflexa, sintetizada por Palu 34 (2001) como sendo aquela em Que "a norma inferior extravasa conteúdo de norma superior (mas não a Constituição), normalmente a lei,

${ }^{32}$ Idem, ibidem, p. 546.

33 É que o sistema jurídico năo está organizado de forma circular, com a Constituiçăo no centro e todos os actos amarrados a ela, a igual distância: em primeiro lugar, porque a Constituição material historicamente surgiu tendo como escopo limitar o poder político [...]; em segundo lugar, porque a complexidade das situações da vida e das intervençŏes do Estado na sociedade impõe a multiplicação e a descentralização de fontes e órgãos de produção jurídica: Domina, antes, como bem se sabe, uma estrutura hierarquizada, em que cada acto jurídico-público tem se assentar, formal e materialmente, num preceito determinado, Que, por seu turno, se funda noutro de grau superior. MIRANDA, Jorge. Tcoria do Estado e da Constituição. Rio de laneiro: Forense, 2002, $546 \mathrm{p}$.

31 PALU, Oswaldo. Controle de Constitucionalidade. Conceitos, sistemas e efeitos. $2^{a}$ Ed. S.Paulo: RT, 2001. 
resultando em juízo de ilegalidade, ainda que possa vir, oblíqua ou reflexamente, atingir a Constituição", e detashada por Bester ${ }^{35}$ (2005):

É a inconstitucionalidade que se estabelece pela via reflexa, ou sę̧a, Que não ofende diretamente a Constituição, parâmetro do controle. Dá-se Quando uma norma inferior é incompatível com uma norma superior, por ter extravasado o seu conteúdo, sem que esta norma superior seja a própria Constítuição.

Ramos (1994) entende Que não há possibilidade de instaurar-se a relação de inconstitucionalidade mediante a interposição de outro ato legislativo interposto, sendo Que o parâmetro da inconstitucionalidade há de ser sempre, direta e imediatamente, uma norma de natureza constitucional:

Cabe determinar, outrossim, se a relação de inconstitucionalidade pode instaurar-se mediante a interposiçăo de outro ato legislativo entre a Constituição-parâmetro e a lei-objeto, de modo oue a desconformidade existirá diretamente entre a lei e o ato interposto e indiretamente com referência às normas constitucionais oue the dão suporte. A resposta se nos afigura negativa, por restringirmos a Questão da inconstitucionalidade legislativa à incompatibilidade direta e imediata entre a lei e a Constituição ${ }^{36}$.

Entretanto, Ramos (1994) não identifica essa hipótese no confronto entre lei complementar e lei ordinária, por entender que ambas possuem campo material próprio de regulação, inocorrendo subordinação hierárquica entre elas, visto que "[...] a relação de superioridade vertical se estabelece Quando sobre a mesma matéria podem incidir dois tipos legislativos, sendo que um deles prevalece sobre o outro, na medida em que condiciona a sua validade [...]". O conflito entre lei complementar e lei ordinária se resolveria em termos de se apurar qual o tipo legislativo adequado ratione materiae, o Que se faz com apoio no texto constitucional. Mesmo a lei complementar que veiculasse normas gerais de direito tributário (art. 146 da Constituição) não comportaria (sic) relação hierárouica com a legislação ordinária, pois ambas teriam campo material específico: aouela regularia as "normas gerais" e esta as "normas específicas" do tributo.

O problema conceitual da inconstitucionalidade indireta ou inconstitucionalidade por ato interpostoé a reduçâo de todas as hipóteses de contrariedade normativa intrasistema à inconstitucionalidade, e, paradoxalmente, a ampliaçāo elástica deste conceito,

35 No Brasil, segundo entendimento do STF, Isto impede o processo objetivo abstrato (ADI 1.347-5), uma vez que se trata de juízo de ilegalidade e năo de inconstitucionalidade, ainda que rellexamente atinja a Constituiçâa. O STF só admite jurisdição concentrada de inconstitucionalidade direta e frontal com a Constituição (AgRg 159.081, rel. Min. Celso de Mello). BESTER, Gisela Maria. Direito Conslitucional, volume 1: Fundamentos Teóricos. São Paulo:Manole, 2005.

36 RAMOS, Elival da Silva. A Inconstitucionafidade das leis: vício e sançăo. São Paulo: Saraiva, 1994. 
Que perde sua utilidade mínima e seu papel de relevo no controle dos atos normativos. A tentativa, ou tentação, de ampliar a noção de inconstitucionalidade pode enfraquecer o próprio conceito, impingindo-lhe um esgotamento por excesso, já que, em tese, todas as violações diretas de normas infra-constitucionais são, indiretamente, violações da Constituição.

Tavares $^{37}$ (2003) apreendeu corretamente o problema e para preservar uma funcionalidade teórica e aplicativa do conceito de inconstitucionalidade, deve-se utilizá-lo em sentido estrito: "[... Inconstitucionalidade, portanto, dá-se apenas entre a lei e a Constituição, numa relação direta, sem Que ocorra Qual Quer intermediação de outros atos jurídicos entre ambas, e Que coloque à norma-objeto outro padrão (intermediário) de validade [...]". Ocorre um complicador Quando é a própria Constituição Que determina Que um ato normativo deve obedecer a um outro ato normativo infra-constitucional, pois, aqui teríamos um caso de "inconstitucionalidade e ilegalidade a um só tempo diretas ${ }^{38 "}$. A resposta a esse problema é dada como negativa por Tavares (2003) com forma de preservar o conteúdo mínimo do conceito de inconstitucionalidade e sua relevância prática como mecanismo de controle de constitucionalidade de normas. Na medida em Que há um confronto entre duas normas não constitucionais, não há inconstitucionałidade em sentido estrito, pois o mandamento constitucional Que impõe obediência de uma norma infraconstitucional a outra, igualmente infraconstitucional, nada mais é do que a reprodução expressa, do ordenamento jurídico como sistema hieráreuico composto por normas jurídicas de diversos graus.

Nesta medida, é também a Constituição Que impede que os decretos extrapolem os limites presentes nas leis Que regulamentam. Em outras palavras, um decreto ilegal seria, ao mesmo tempo, inconstitucional, porque a própria Constituição ordena Que os decretos restrinjam-se às leis. Quando a análise é aplicada à lei complementar, todavia, as premissas da construção teórica do autor não são aplicadas em suas conclusões; este entende Que não há relação de hierarquia entre a lei complementar e a lei ordinária, mesmo nos casos em Que aquela fosse do tipo continuável (classificação de Celso Bastos), pois, tratar-se-ia sempre de atuação (das duas espécies nomativas) em âmbitos próprios (distintos) de competência, sem relaçăo de subordinação hierárquica. Essa posição é mitigada pela referência feita à hipótese

${ }^{37}$ Fica evidente, pois, Que todas as violações normativas seriam reduziveis a uma Questão de incoristitucionalidade (entendida aqui em sentido amplíssimo), tendo em vista que a Constituiçăa é sempre o fundamento último de validade de todas as demais normas do sistema, estejam estas situadas no nível de uma portaria, de mera instrução ou mesmo no nível de lei. Em outras palavras, a ilegalidade, por infração de uma norma infraconstitucional, ou a invalıdade, por infraçăo de uma norma infralegal, sempre podem ser conduzidas em termos de violação indireta da norma hierareuicamente superior àQuela violada diretamente, até se alcançar a Constituiçăo.TAVARES, André Ramos. Curso de Diretto Constitucional. 2a Ed. São Paulo: Saraiva, 2003.

38 TAVARES, André Ramos, op. cit., p. 184. 
do art. 22, § único, da Constituição, em que é admitida a hierarquia entre lei federal e estadua ${ }^{39}$, e a hipótese de Que atos normativos Que se situam num mesmo nível possam ser considerados norma-parâmetro e norma-objeto, na medida em Que a relação entre um e outro está determinada constitucionalmente ${ }^{40}$.

\subsection{A jurisprudência oscilante do STJ e do STF: posiçốes contraditónias e o uso instrumental e casuístico das teorias}

Um balanço da j̧urisprudência do Superior Tribunal de lustiça e do Supremo Tribunal Federal revela um posicionamento não uniforme em relação à conseqüência aferível do confronto entre lei complementar e lei ordinária.

Como o escopo do trabalho defluiu de uma tentativa de sistematização das hipóteses consequenciais do confronto no campo tributário, a análise das decisões restringiu se às interpretaçóes conferidas aos incisos do artigo 146 da Constituição. No Superior Tribunal de lustiça, dois conjuntos de decisões são identificados, em relação ao art. 146, inciso III, alíneas "a" e "b": um que interpreta o conflito como possuindo natureza constitucional e outro Que interpreta o conflito como possuindo natureza infraconstitucional. Analisar-se-á, primeiramente, a alínea "a”.

A posição Que atribui natureza constitucional ao conflito fundamenta-se na teoria da invasão de competência, segundo a Qual o reconhecimento da incompatibilidade entre lei ordinária e lei complementar se resolve a favor do texto integrado em lei complementar, mediante juízo de inconstitucionalidade, pois, nesse caso, a lei ordinária ofende a Constituição por invadir competência que esta reservou à lei complementar. A consolidação dessa posição no âmbito do Superior Tribunal de Justiça tem seus precedentes nos sucessivos votos do Ministro Ari Pargendler ${ }^{41}$, cujo leading case parece estar no voto proferido no Resp $71.639 / \mathrm{MG}^{42}$, cuja ementa ficou assim registrada:

39 Em tal caso, sendo a competência legislativa privativa da União, e em havendo lei complementar desta que autorize Estados a editarem leis em questōes específicas (delegadas a esses entes), pode-se dizer que essa legislaçäo aufere seu fundamento de validade diretamente na lei de delegaçäo (federal) e só mediatamente na própria Constituiçăo Federal. TAVARES, André Ramos, op. cit., p. 187.

40 TAVARES, André Ramos, op. cit., p. 185.

41 No mesmo sentido, os ministros Francisco Peçanha Martins: Resp 167.014/RS; REsp 129.644/RS; REsp 225.391/SC; REsp 148.988/RS; REsp 226.511/PR; Teori Albino Zavascki: REsp 381.406/PR (discute-se a contrariedade da Leì 8.541/92 com o art. 43 do CTN); Humberto Gomes de Barros: REsp 413.611/SC; REsp 436.380/PR; Garcia Vieira: RESP 255.544/AL; Francisco Falcão: AgRg no REsp 287.766/PR; AgRG no REsp 298.423/PR; Hélio Mosimann: REsp 97.946/SC; REsp 108.123/PF; REsp 106.317/RS; REsp 98.166/RS;

42 No Resp 76.652/RS, o confronto entre a lei ordinária (art. 30, $\$ 1^{\circ}$, da Lei 7.730 , de 1989 e art. 30 , caput, da Lei 7.799, de 1989) e a lei complementar (art. 43 do Código Tributário Nacional) ficou assim decidido: Eventual contrariedade do artigo 30, par. 10, da lei 7.730, de 1989, com o art. 43 do Código Tributário Nacional não pode ser examinada no âmbito do recurso especial; trata-se de matéria própria de recurso extraordinário, porque, a ser demonstrado, no caso, que lei ordinária usurpou competência reservada pela constituição federal, incide ela em inconsitucionalidade, e năo em mera ilegalidade, segundo os iterativos pronunciamentos do S. Tribunal Federal. 
A. Conseaüencia Juridia do Conflita Nornative untre a lei Ordinária

CONSTITUCIONAL. ANTINOMIA ENTRE LEI ORDINARIA E NORMA GERAL DE DIREITO TRIBUTARIO DISPOSTA EM LEI COMPLEMENTAR. CONFLITO QUE SE RESOLVE PELA INCONSTITUCIONALIDADE.DA LEI ORDINARIA. A lei ordinária deriva sua validade diretamente da constituição, de modo Que, se invadir área reservada a lei complementar, afronta o texto básico, caracterizando-se como inconstitucional. O acórdão Que, para decidir o litígio, enfrenta essa questão esta sujeito a recurso extraordinário $[. . .]^{43}$.

Pargendler ${ }^{44}$ (1999) identifica três grupos de questões cuja competência é indefinida entre o Supremo Tribunal Federal e o Superior Tribunal de Justiça, sendo o $3^{\circ}$ grupo o Que se alega incompatibilidade entre leis ordinárias (federais, estaduais ou municipais) e normas gerais de Direito Tributário estabelecidas por lei complementar ou pelo Código Tributário Nacional, Que é uma lei ordinária com força de lei complementar ${ }^{45}$ : Questão debatida pelo Tribunal Federal de Recursos no julgamento da Argüição de Inconstitucionalidade na AMS no 89.825/RS, em Que a teoria da invasão de competência foi aplicada ${ }^{46}$. No REsp 644.497/ MG, o Ministro Luiz Fux ${ }^{47}$, adota a mesma conclusão, mas aplica como fundamento a "inconstitucionalidade reflexa", numa singular interpretação;

TRIBUTÁRIO - ANTECIPAÇÃO DO PAGAMENTO DO IRP] - VIOLAÇÃO AO ART. 43, DO CTN - MATÉRIA DE NATUREZA CONSTITUUCIONAL COMPETÊNCIA DO STF - PRETENSÃO DE DECLARAÇÃO REFLEXA DE INCONSTITUCIONALIDADE. 1. Concluindo o aresto recorrido que a lei Que autoriza a antecipação do pagamento do IRPI (artigo $8^{\circ}$, da Lei n. ${ }^{\circ}$ 9.430/96) contraria o disposto no artigo 43, do Código Tributário Nacional, Que reproduz texto constitucional, significa, por via reflexa, afirmar a inconstitucionalidade de referida disposição, matéria apreciável pelo Colendo Supremo Tribunal Federal, guardião dos comandos constitucionais.

${ }^{43}$ No caso, Questionava-se o confronto entre o art. 35 da Lei 7.713, Je 1988, ante o ant. 43 do CTN.

44 PARGENDLER, Ari. O Recurso Especial e o Código Tributário Nacional. ST): Dez Anos a Serviço da fustiça: Doutrina - ed. comemorativa. Brasília: Superior Tribunal de lustiça, 1999.

45 Os outros dots grupos são: a) $1^{\circ}$ grupo -... em que o desate da lide depende de saber se a lei anterior à Constituição Federal de 1988 foi recepcionada ou revogada por ela: o STJ entendia Que o fenômeno da recepção seria de sua competência, até que o STF decidiu o contrário; b) $2^{\circ}$ grupo - em que o recurso especial alega que o julgado contrariou norma legal Que repete norma constitucional: Questão mais complexa, em que não há posição unívoca de ambos os tribunais a respeito.

4 $\mathrm{O}$ Egrégio Tribunal Federal de Recursos declarou a inconstitucionalidade do Decreto-Lei no 1.582 , de 1977, porque, ao definir o fato gerador do Imposto sobre Transportes Rodoviários, deixou de observar o art. 68, 1, do Código Tributário Nacional. Entretanto, houve voto-vencido do Ministro Sebastião Reis: "[...], só há de falar-se em controvérsia constitucional, Quando a colisão da Lei menor com a Lei Magna se instaura direta e imediatamente, interpretação restritiva que se impöe, principalmente quando se considera nas cautelas constitucionais em torno da decretação do vício máximo e a tradição de nossa jurisprudência e doutrina no sentido de evitar-se o confronto com a Constituição, Quando a discrepância pode ser dirimida num cotejo de normas infraconstitucionais".

47 Também de luiz fux: REsp 460.986/PR; REsp 476.995/MG; REsp 441 .219/RS; AgRg no Ag 586.137/PR. 
A posição Que atribui natureza infraconstitucional ao conflito fundamenta-se na teoria da inconstitucionalidade reflexa, segundo o qual o confronto entre a lei ordinária e o Código Tributário Nacional (lei ordinária com eficácia de lei complementar) é inconstitucional apenas por via reflexa, ou indireta, o Que enseja o recurso especial, e tem na Ministra Eliana Calmon sua mais destacada formuladora e defensora, cujo leading case está no EDcl no REsp $\mathrm{n}^{\circ} 226.062 / \mathrm{SC}^{48}$ :

PROCESSO CIVIL E TRIBUTÁRIO - EMBARGOS DE DECLARAÇÃO CONFRONTO ENTRE LEI ORDINÁRIA E LEI COMPLEMENTAR MATÉRIA INFRACONSTITUCIONAL. I. A Questão constitucional só admite recurso extraordinário Quando enfrentada claramente pela decisão recorrida. 2. Princípios constitucionais Que chegam aos julgados por via reflexa, princípios estes contidos na Lei de Introdução ao Código Civil, podem ser examinados pelo STI, em exame infraconstitucional. 3. O confronto da lei ordinária com o CTN é constitucional apenas por via reflexa, o Que enseja recurso especia ${ }^{49}$.

Calmon (2000) considera que a incompatibilidade entre a lei ordinária e a lei complementar é de indole infraconstitucional, pelos seguintes fundamentos:

a) se a discussão do confronto foi solucionada nas instâncias ordinárias em nível infraconstitucional, não há como chegar ao STF pelo recurso extraordinário;

b) se no ST) a Questão é examinada confrontando as leis, a ordinária e a complementar, ainda não há exame da Constituição, senão por via reflexa;

c) por via reflexa, chega-se à Constituição Federal, porque o ST], como na hipótese, concluiu pela prevalência da lei complementar.

Ainda Que, em alguns casos, não se tenha debatido expressamente Qual a natureza do conflito normativo, inúmeros julgados dos ministros da corte decidiram a Questão como sendo infraconstituciona ${ }^{50}$. Na maioria desses julgados, ou se defluiu, expressamente, a Quaestio júris como sendo infraconstitucional, na medida em que os julgados esboçaram de forma explícita os fundamentos teóricos que lihe deram embasamento (via de regra, a "teoria da inconstitucionalidade reflexa"), ou a natureza infraconstitucional é constatada, implicitamente, Quando os ministros admitem, de forma tácita, julgar recursos cuja matéria é o confronto entre lei ordinária e o CTN. Umm outro conjunto de julgados chegou à mesma

\footnotetext{
48 A matéria em julgamento é o confito entre a lei ordinária $n^{\circ} 9.430 / 96$ e a kei complementar $n^{\circ} 70 / 91$.

4No mesmo sentido, tendo como relatora a Ministra Eliana Calmon: EDcl no REsp 227.942/RS; com a mestna conclusão, mas jułgando o confronto entre a Lei 8.541/92 e o art. 43 do CTN: REsp 226.978/PR.

\$) Min. Demócrito Reinaldo: REsp 166.868/SC, cuja matéria julgada fó o confronto entre a Lei 8.541/92 e o art. 43 do CTN; Franciulli Neto: REsp 642.686/MG; Milton Luiz Pereira: REsp 193.084/MT; José Delgado:REsp 129.249/RS; Garcia Vieira: REsp 202.040/PR; REsp 227.931/SC; REsp 217.562/RS; REsp 203.973/PR
} 
conclusão sobre a natureza infraconstitucional do conflito, mas com base na "teoria da hierarquia", e levou a edição da Súmula no 276.

A definição jurisprudencial do conflito entre a lei ordinária e a complementar encerra uma oscilante e contraditória postura do Superior Tríbunal de Justiça Quando a analise recai sobre a alínea "b", do inciso III, do art. 146, da Constituição. Com efeito, os mesmos ministros Que cerraram firme posição ao definir como sendo inconstitucionalidade o vício decorrente do conflito (ouando as decisões se referiram a alínea "a" do inciso Ill do art. 146), agora defendem o contrário (vício de ilegalidade), posicionando-se sobre a prevalência das regras contidas no Código Tributário Nacional sobre regras de lei ordinária Que trate de prescrição e decadência tributárias. Os julgados admitem, implicitamente, a possibilidade da confrontação infraconstitucional da lei ordinária tributária, a Qual deve estar submetida à norma geral de direito tributário, o CTN; nesse particular, a jurisprudência que se pacificou no ST) é no sentido de que o CTN (art. 174) prevalece sobre a Lei ${ }^{\circ} 6.830 / 80$ (lei de execuções fiscais). O REsp no $132.846 / \mathrm{PR}$, cuja ementa se transcreve, ilustra esta posição, tendo como relator para o acórdão o Ministro Demócrito Reinaldo ${ }^{51}$ :

PROCESSUAL CIVIL. TRIBUTÁRIO. PRESCRIÇÃO INTERCORRENTE. ART. 40 DA LEI No $6830 / 80$ E ART. 174 DO CTN. A jurisprudência que se pacificou no ST] é no sentido de que, o Código Tributário Nacional (art. 174), por Lei Complementar, prevalece sobre a Lei n ${ }^{\circ} 6830 / 80$, Que é Lei ordinária. A suspensão do processo de execução fiscal (art. 40 da Lei 6830/80) há de compatibilizar com a regra prevista no art. 174, I, do CTN, de modo a que o débito tributário não se torne imprescrit́vel, Quando já em fase de execução.

Esta posição já havia se uniformizado em julgados anteriores da corte, cujo leading case foi o REsp 1.924/PR, Que teve como relator Ministro losé de lesus Filho. Desde então (o julgado é de (990), a jurisprudência do ST) alinhou-se a este posicionamento ${ }^{52}$. A

51 No mesmo sentido, e tendo como relator o Min. Demócrito Reinaldo: REsp 154.012/PR; REsp 140.172/ SP; REsp II1.61।/PR; REsp 88.999/RS; REsp 85.178/PR; REsp 171.272/SP; REsp 165.219/RS.

${ }^{52}$ Min. losé Delgado: REsp 218.286/SP; REsp 249.262/DF; REsp 228.093/SP; AgRg no REsp 241.530/ PE; AgRG no REsp 227.793/SP; EREsp 85. 144/R;; AgRg no REsp 443.971/PR; AgRg no REsp 503.785/ RO; AgRg no REsp 503.376/RO; REsp 258.137/SP; REsp 695.881/Rl; REsp 570.771/SP; Adhemar Maciel: EREsp 97.328/PR; REsp 67.300/PR; REsp 168.964/SP; César Asfor Rocha: REsp 36.855/SP; Hélio Mosimann; REsp 34.3I8/PR; Antonio de Pádua Ribeiro: REsp 36.31 1/SP; REsp 36.855/SP; Eliana Calmon: REsp 123.392/SP; REsp 55.65I/RS; AgRg no Ag 157.520/SP; REsp 178.500/SP; REsp 46.131/SP; Francisco Peçanha Martins: REsp 12.443/RN; REsp 106.816/PR; REsp 43.354/PR; REsp 76.739/RS: REsp 152.390/SP; REsp 95.421/RS; REsp 88.807/MG; AgRg no Ag 339.04I/RS; REsp 194.296/SC; REsp 263.661/MG; AgRg no Ag 541.255/RS; Nancy Andrighi: REsp 237.079/SP; Garcia Vieira: REsp 227.772/SP; REsp 235.202/RO; REsp 346.230/SP; Milton Luiz Pereira:REsp 67.254/PR; REsp 81.832/RS; REsp 182.429/PR; Humberto Gomes de Barros: REsp 198.755/SP; REsp 178.399/ SP; REsp | |4.609/SP; AgRg no REsp 251.216/SP; Luiz Fux: REsp 331.484/PE; REsp 401.525/R|; RE 524.692/ES; REsp 524.680/ES; REsp 511.878/BA; REsp 556.644/RO; REsp 671.517/RS; REsp 618.644/PE; REsp 669.393/Rj; Francisco Falcäo: AgRg no Ag 550.208/MG; AgRg no Ag 568.680/ MG; AgRg no Ag 341.556/SP; AgRg no Ag 376.799/SP; Denise Arruda: AgRg nos EDcl no REsp 623. 104/R]; Franciulli Neto: REsp 502.740/PR; Castro Meira: REsp 673.162/RJ. 
única exceção a este entendimento foi encontrada no voto do Ministro Teori Albino Zavascki, Que foi coerente com seu voto adotado em relação à alínea "a" do inciso llI do art. 146, adotando o entendimento de que se trata de vício de inconstitucionalidade, como se aufere no AgRg no RESP 616.348/MG:

As contribuições sociais, inclusive as destinadas a financiar a seguridade social (CF, art. 195), têm, no regime da Constituição de 1988, natureza tributária. Por isso mesmo, aplica-se também a elas o disposto no art. 146, III, b, da Constituição, segundo o Qual cabe à lei complementar dispor sobre normas gerais em matéria de prescrição e decadência tributárias, compreendida nessa cláusula inclusive a fixação dos respectivos prazos. Conseqüentemente, padece de inconstitucionalidade formal o artigo 45 da Lei 8.2 12, de 1991, Que fixou em dez anos o prazo de decadência para o lançamento das contribuições sociais devidas à Previdência Social,

Na função da lei complementar estabelecer o adequado tratamento ao ato cooperativo (art. 146, inciso III, " $c$ ", da Constituição) prevalece, no Superior Tribunal de Justiça, a tendência de auferir como infraconstitucional o vício decorrente do conflito. No confronto entre a lei complementar 70/91 (instiłuiu isenção para cooperativas) com a lei 9.718/98 (revogadora da isençäo) entendeu o ST|, Que a referida LC 70/91 deu o adequado tratamento ao ato cooperativo, ostentando formal e, materialmente, natureza de lei complementar. Resolveu o conflito como vício de ilegalidade e com base na "teoria da hierarquia", como expressa o REsp 543.828/MG, relator o Min. Castro Meira:

TRIBUTÁRIO. SOCIEDADES COOPERATIVAS. COFINS. ATOS COOPERATIVOS. NÄO-INCIDÊNCIA. ART. $6^{\circ}$, I, DA LC No 70/91. REVOGAÇÃO. INOCORRÊNCIA. PRINCÍPIO DA HIERARQUIA DAS LEIS. [...] 4. O art. 6० , I, da $\mathrm{LC}$ n $^{\circ} 70 / 91$, apesar de utilizar a expressão "são isentas", veicula uma regra de cunho eminentemente explicativo e deciaratório, cuja doutrina acostumou-se a chamar de norma de não-incidência didática. 5 . Por se tratar de norma sob referência declaratória e năo constitutiva de direitos, não há que se falar em revogação. 6 . Ainda que se tratasse de isenção, a regra contida no art. $6^{\circ}, \mathrm{I}$, da $\mathrm{LC}$ n $^{\circ} 70 / 9$ I não poderia ser revogada por norma de inferior hierarquia Lei $n^{\circ}$ 9.718/98. Inteligência do princípio da hierarquia das leis. 7. O art. 146, III, "c", da Carta Magna, coloca sob reserva de lei complementar a regra que disponha sobre o "adequado tratamento tributário" a ser dispensado ao ato cooperativo ${ }^{53}$.

53 Também tendo como relator o Min. Castro Meira: REsp 614.764/MG; REsp 546.380/MG; REsp 544.194/ MG; no mesmo sentido, Eliana Calmon: REsp 388.921/SC: REsp 625.270/MG; Luiz Fux: REsp 616.219/ MG: Francisco Peçanha Martins: REsp 463.022/RS. 
Em relação ao Art. 146, inciso I, da Constituiçãa ${ }^{54}$, há precedentes do Superior Tribunal de Justiça em resolver o hipotético conflito de competência, arvorando para si, portanto, a resolução do conflito entre a lei complementar Que fixa o critério de resolução do conflito e a(s) lej(s) ordinária(s) Que o contrariam, delineando, implicitamente, a natureza infraconstitucional e o vício de legalidade dele resultante. No caso do conflito de competência materia/dois entes tributantes intentam buscar a incidência tributária sobre o mesmo fato gerador, tendo em vista divergência sobre a natureza da materialidade Que o integra.

Em outras palavras, dois entes tributantes entendem ser competentes para instituição de tributo de sua competência sobre o mesmo fato gerador, por visualizarem-no dentro do seu campo de incidência. Veja-se o item $32^{55}$ da lista de serviços do ISS anexa ao DecretoLei 406/68; este item teve interpretação dada pelo ST] em relação ao concreto feito em caminhão betoneira ou equivalente, no sentido de Que não incidiria o ICMS, pois o concreto seria feito em trânsito, tendo sido editada a Súmula no 167, cujo teor é o seguinte " $O$ fornecimento de concreto, por empreitada, para construção civil, preparado no trajeto até a obra em betoneiras acopladas a caminhôes, é prestação de serviço, sujeitando-se apenas à incidência do $/ 5 S^{\prime \prime 56}$. Houve fixação de resolução de conflito aparente de competência entre o ISS (de competência dos Municípios) e o ICMS (de competência dos Estados-membros).

O segundo tipo de conflito entre entes políticos tributantes pode se dar no conflito territorial de competência, Que se resume em saber qual o local de ocorrência do fato gerador da obrigação tributária. Em outros termos, Qual os limite territorial de abrangência da lei do ente tributante que instituiu o tributo? Se o fato gerador ocorreu em outro lugar. Que não em seu território, como se conciliaria o aspecto material da hipótese de incidência com o aspecto espacial da hipótese de incidência.

Na vigência do Decreto-Lei 406/68, a jurisprudência do ST) pacificou seu entendimento pela territorialidade da lei, conforme ilustra o EDREsp $n^{\circ}[68.023 / \mathrm{CE}$, Que teve como relator o Ministro Paulo Galotti:

54 Entendemos que há duas funçöes na determinação constitucional referida: 1) evitar que haja a concomilância de incidência de dois entes tributantes sobre o mesmo fato gerador (conflito de competência material); 2) evitar Que haja a exigibilidade do mesmo tributo por dois entes tributantes (conflito de competência territorial).

5ร 32-Execução, por administração, empreitada ou subempreitada, de construção civil, de obras hidráulicas e outras semethantes e respectiva engenharia consultiva, inclusive serviços auxiliares ou complementares fexceto o fornecimento de mercadorias produzidas pelo prestador de serviços, fora do local da prestação dos serviços, Que fica sujeito ao ICM).

56 Elenca-se mais dois casos de resolução jurisprudencial de conlitito de competência, também pelo ST]: Súmula $n^{\circ} 163$ (O fornecimento de mercadorias com a simultânea prestação de serviços em bares, restaurantes c estabelecimentos similares constitui fato gerador do ICMS a incidir sobre o valor total da operação) e Súmula $n^{\circ} 156$ (A prestação de serviço de composiçăo grálica, personalizada e sob encomenda, ainda que envolva fornecimento de mercadorias, eslá sujeita, apenas, ao ISS). Ambas as súmulas do ST] resolvem dois conflitos de competência material entre Estados e Municípios o Que revela a aplicabilidade e funcionalidade da previsăo normativa contida no inciso I do art. I 46 da Constituição. 
“Tributário. Iss. Fato Gerador. Município. Competência Para Exigir O Tributo. I. O município competente para exigir o ISS é aQuele onde o serviço é prestado. 2. Precedentes. 3. Recurso conhecido e rejeitado."

Para o nosso Questionamento, o relevante é que o ST| admite, implicitamente, sua competência para a resolução dos hipotéticos conflitos de competência entre entes tributantes, - Que revela o caráter infraconstitucional aplicável ao confronto da lei complementar com a lei ordinária. Ou seja, Quando o STI interpreta a lei complementar definindo que um ente tributante (em detrimento de outro ente tributante) é competente para instituir determinado tributo (no caso do conflito material de competência) ou entendendo que o tributo deve ser cobrado em determinado local (no caso do conflito territorial de competência) o ST) está atribuindo caráter vinculativo à lei complementar: a lei ordinária do ente tributante que não foi contemplado na interpretação dada pelo ST] ou não poderá ser aplicada no caso concreto ou, se apłicada, será ilegal em confronto com a regra da lei complementar (vício de ilegalidade).

Assim como o ST\}, o Supremo Tribunal Federal tem sido pródigo em não sistematizar seu posicionamento a respeito do conflito entre a lei complementar e a lei ordinária, possuindo decisões conflitantes sobre a natureza do conflito, não havendo uma uniformidade passível de identificação na análise de sua jurisprudência. Os julgados Que tratam da matéria, diretamente, no campo tributário são mais escassos que no ST], e, mais evidente do que as decisões daquele tribunal, a matéria é, via de regra, explicitada nos votos dos ministros.

É antiga a posição no STF de Que o conflito entre lei complementar e lei ordinária resolve-se com a "teoria da invasão de competência legislativa". Este posicionamento já fora adotado no RE 84.994/SP, tendo como relator o Min. Xavier de Albuquerque, no RE 90.332/SP, cujo relator fol o Min. Soares Muñoz, e na Representação 1.141/MA, relator o Min. Décio Miranda.

No mesmo sentido, tendo como relator o Min. Moreira Alves, o RE no 100.642/ $\mathrm{SP}^{57}$ e o RE $101.339 / \mathrm{SP}^{58}$; tendo como relator o Min. Aldir Passarinho, o RE ${ }^{\circ}$ 101.083/SP5; tendo como relator o Min. Marco Aurélio, o RE 172.058 - $/ \mathrm{SC}^{60}$ e o RE 407.190/RS ${ }^{61}$. Como já visto, a "teoria da invasão de competência" legislativa resulta no vício de inconstitucionalidade. As decisões referidas tratam de situações de confronto das hipóteses do art. 146, III. "a", da Constituição. Em relação ao inciso Il, do art. 146, o tribunal enfrentou o contraste entre a lei complementar reguladora das limitaçóes

\footnotetext{
77 No mesmo sentido, o RE 101.084/PR, RE 101.191/SP, RE 101.878/MG, RE 101.170/SP, RE 101.336/ PR, RE 100.795/SP, RE 101.073/SP, RE 101.946/RS, RE 101.464/SP.

${ }^{58}$ Os três fecursos trataram do confronto entre o CTN e o Decreto-Lei $n^{\circ} 1.438 / 75$.

59 Tratou, também, do confronto entre o CTN e o Decreto-Lei $n^{\circ} 1.438 / 75$.

60 Tratou do confronto entre o CTN e a Lei 7.713/88.

61 Tratou do confronto entre o CTN e a Lei $8.2312 / 91$.
} 
constitucionais ao poder de tributar (o CTN) e a lei ordinária, nos casos da lei 9.532/97 (ADI 1.802 DF, Rel. Min. Sepúlveda Pertence) e das leis 8.212/9 I e 9.732/98 (ADI 2.0285/DF, rel. Moreira Alves), segundo o Qual ficou assentado Que a lei ordinária Que contrariar dispositivo da lei complementar Que regulamentou limitaçâo constitucional ao poder de tributar é inconstituciona/. Não obstante os estudos doutrinários brasileiros afirmarem Que este é um posicionamento uníssono do Supremo Tribunal Federal sobre a matéria, há decisões que abordam-na sob outro enfoque, o da "teoria da inconstitucionalidade reflexa", concluindo pela ocorrência do vício de ilegalidade como na Questâo de Ordem no RE no 117.809/PR, Rel. Min. Sepúlveda Pertence, na cual se extrai o seguinte excerto de seu voto: "[.... Do mesmo modo, é de reputar de llegalidade e não de inconstitucionalidade o vício da lei estadual incompativel com a lei federal à eual deva observância, segundo a Constituiç̧ão ${ }^{62 "}$. Na ADI 1.540-1/MS $\mathrm{MS}^{63}$ o voto do Min. Maurício Correia ${ }^{64}$ adota o mesmo fundamento, Que é mantido na Questão de Ordem na $\mathrm{ADI}$ 2344/SP, rel. o Min. Celso Mello:

${ }^{62}[$ [...] a aferição da validade da própria lei local em face de lei federal pode resurnir-se a uma indagação de legalidade e não de constitucionalidade. Certo, no federalismo dualista clássico, a regra é ser a relação entre a lei federal e a lei estadual não um problema de hierarquia, mas sim, de competência. E só no caso de que se trate de um problema de competência é que efetivamente a prevalência de uma ou de outra resultará necessária e diretamente da Constituição Federal [...]. Mas, como também ć sabido, na prática do federalismo, essa repartição constitucional de competências conhece duas técnicas diversas. A primeira, típica do federalismo cássico, é a que Raul Machado Horta denominou 'repartição horizontal de compelências' (Autonomia do Estado membro..., Belo Horizonte, 12964, f. 49 ss.), Que consiste na discriminaçăo das matérias em dois círculos, entregues, a título de competência exclusiva, um à ordem central, e, o outro, a cada uma das ordens estaduais, no limite do". território respectivo. [...] na técnica da "repartição vertical de competência, que realiza a distribuiçăo de idêntica matéria legistativa entre a União e os Estados-membros, estabelecendo condomínio legislativo consoante regras constitucionais de convivência. Dessas 'regras constitucionais de convivência' entre órbitas da competência concorrentes, a mais comum é a da prevalência de lei federal, anterior ou posterior, sobre a lei local atinente à mesma matéria [...] Na esfera da técnica de repartição vertical, invertem-se, pois, os tenmos dae equação do federalismo clássico: a relação entre lei federal e lei estadual deixa de ser uma questão de competêncìa, que, em tese, é comum à União e aos Estados, para reduzir-se a uma questão de hierarquia de normas (cF. Pontes de Miranda, Comentários à Cosntítuição de 946, 1953, 1/44I). Ora, problema de hierarouia normativa entre preceitos infraconstitucionais - ainda, como é normal, que a regra da prevalência provenha de Constituição - não é, senão mediatamente, uma questão constitucional. Assim, a jurisprudência da Corte tem entendido que o regulamento ofensivo da lei regulamentada não é inconstitucional, mas ilegal c, por isso, insusceptivel de submissão aos mecanismos peculiares ao controle de constitucionalidade.

${ }_{63}$ No mesmo sentido: AgRg na ADI 1.035/SC, relator Min. Carlos Velloso; ADI 384 4/PR e ADI 252-0/ PR, relator o Min. Moreira Alves.

ज4 [...] A regulamentaçäo das promoções dos policiais militares insere-se no capítulo que dispốe sobre as normas gerais de organizaçäo dos poliçais-militares. Estas normas gerais, por sua vez, estão sob reserva de lei federal, consoante dispốe o art. 22, XX], da Constituição. [...] Vê-se que o impugnado art. 57, na sua atual redação, não obedece aos parâmetros fixados pelo art. 24 do Decreto-lei n $n^{\circ} 667 / 69$ nem pelo art. 62 da Lei no $6.880 / 80$. Destas ponderaçóes conclui-se que a disposiçẵo legal questionada afronta diretamente à lei federal, e não à Constituiçăo, e, em conseqüência, sendo o caso de ilegalidade, não pode ela ser objeto de ação direta de inconstitucionalidade E do excerto do voto do Min. Sepúlveda Pertence extrai-se o argumento da inconstitucionalidade reflexa: [... T Teríamos aí, o caso típico da chamada inconstitucionalidade por violação da norma ordinária interposła Que - como na prática, por exemplo, da Corte Constitucional italiana (e Zagrebelsky o demonstra exaustivamente), não se tem considerado matéria adequada ao controle abstrato da constitucionalidade das normas que é o obje to da ação direta [...]. 
Nas hipóteses de competência concorrente ( $\mathrm{CF}$, art. 24), nas Quais se estabelece verdadeira situação de condomínio legisłativo entre a União Federal e os Estados-membros (RAUL MACHADO HORTA, "Estudos de Direito Constitucional", p. 366, item n. 2, 1995, Del Rey), daí resultando clara repartição vertical de competências normativas, a jurisprudência do Supremo Tribunal Federal firmou-se no sentido de entender incabível a ação direta de inconstitucionalidade, se, para o específico efeito de examinar-se a ocorrência, ou não, de invasão de competência da União Federal, por parte de Qualeuer Estado-membro, tornar-se necessário o confronto prévio entre diplomas normativos de caráter infraconstitucional: a legislação nacional de princípios ou de normas gerais, de um lado ( $\mathrm{CF}$, art. $24, \S 1^{\circ}$ ), e as leis estaduais de aplicação e execução das diretrizes fixadas pela União Federal, de outro (CF, art. $24, \S 2^{\circ}$ ). Precedentes. É Que, tratando-se de controle normativo abstrato, a inconstitucionalidade há de transparecer de modo imediato, derivando, o seu reconhecimento, do confronto direto que se faça entre o ato estatal impugnado e o texto da própria Constituição da República. Precedentes.

E, ainda, no AgRg no RE 274.362/RS, a Min. Ellen Gracie julgou Que o acórdão recorrido julgara o confronto entre normas de índole ordinária (CTN e Lei 8.212/ 91). e o conflito de normas infraconstitucionais não se reveste de conteúdo constitucional, impedindo a admissão do recurso extraordinário. Observa-se que a jurisprudência de nossas duas principais cortes não oferece critérios coerentes e estáveis para resolver o problema proposto: ao contrário, o uso indiscriminado e casuístico de teorias conflitantes leva a um estado de incerteza sobre Quem tem a competência para controlar o confronto entre as duas espécies normativas.

\section{INTER-RELAÇÃO DA TEORIA DA HIERARQUIA COM AS FUNÇÕES DA LEI COMPLEMENTAR NO SISTEMA CONSTITUCIONAL TRIBUTÁRIO}

Analisada a teoria da hierarquia entre a lei complementar e a lei ordinária, cumprenos identificar as funções daQuela no sistema constitucional tributário, pois há decorrente inter-relação entre a teoria da hierarQuia, a função exercida pela lei complementar e as conseQüências do conflito normativo desta com a lei ordinária. Em outras palavras, a hierarquia da lei complementar tributária depende da função específica Que esta exerce no sistema constitucional. 


\subsection{Tipologia das funções da lei complementar no sistema tributário}

Coetho $^{65}$ (1999) explica o lugar da lei complementar no ordenamento jurídico através de seu enlace com a teoria do federalismo. Arrimado em Kelsen, e, utilizando-se do âmbito de validade espacial das leis (o espaço político onde a lei tem vigência e eficácia, onde produz efeitos), Coelho (1999) distingue as leis Que são válidas em todo o território do Estado federal (normas centrais) das que são válidas apenas para determinadas partes desse mesmo território (normas parciais), pois há uma ordem jurídica total (nacional) formada por três ordens juridicas parciais (federal, estadual e municipal), todas tendo seu fundamento de validade na ordem constitucional.

O órgão de emissão da lei complementar é o mesmo que emite a lei federal ordinária (o Congresso Nacional), e seu âmbito de validade espacial é igual ao âmbito da lei federal, não havendo ai diferenciação entre a lei complementar $e$ as leis federais. A distinçâo está no papel desenvolvido pela lei complementar relacionado a fazer atuar determinações constitucionais de interesse de toda a Nação, para fins de complementação e atuação constitucional, como detalha Coelho (1 999):

[...] a lei complementar está a serviço da Constituição e não da União Federal. [...] Por isso mesmo, por estar ligada à expansão do texto constitucional, a lei complementar se diferencia da lei ordinária federal que, embora possua também âmbito de validade espacial nacional, cuida só de matérias de interesse ordinário da União Federal, cuja ordem jurídica é parcial, tanto Quanto sāo parciais as ordens jurídicas dos Estados-Membros e dos Municípios. A lei complementar é, por excelência, um instrumento constitucional utilizado para integrar e fazer atuar a própria Constituiçãa $0^{66}$.

A sede jurídica de estudo das normas gerais de direito tributário situa-se na teoria do federalismo e, mais especificamente, na repartição das competências legislativas nos Estados Federais, nos Quais Horta ${ }^{67}$ (1995) aponta duas espécies: repartição horizonta/(as pessoas políticas, isonômicas, recebem cada Qual suas áreas de competência devidamente delimitadas e apartadas) e repartição vertica/ (o discriminese faz por graus, pois as matérias são regradas por mais de uma pessoa política - também denominada competência concorrente). Coelho (2000) fornece três aclaramentos:

${ }_{65}$ COELHO. Sacha Calmon Navarro. A Lei Complementar como Agente Normativo Ordenador do Sistema Tributário e da Repartiçăo de Competências Tributárias. $8^{\circ}$ Simpósio Nacional lOB de Direito Tributário, São Paulo, p. 135-149, 1999.

th Ainda que concordemos com Sacha em sua asserliva genérica, é certo Que Borges (1975) já criticara a identificação necessária entre lei complementar e lea nacional, pois " $[.$. ) a análise do conteúdo das diversas leis complementares previstas na Constituiçăo evidencia que elas não assumem sempre a feição de le nacional, embora esta seja a regra, sendo que há leis ordinárias que regulam matéria de lei nacional, no que é possível a distinção entre leis ordinárias federais e leis ordinárias materialmente nacionais [...]".

b HORTA, Raul Machado. Estudos de Direito Constitucional. B.Horizonte: Del Rey, 1995. 
A) lei complementar é veículo legislativo, e, norma geral, conteúdonormativo, ou lei = forma e norma geral = conteúdo;

B) a norma geral de Direito Tributário condiciona as legislações tributárias da União, Estados e Municípios enquanto lex legum, loi de cadre, no dizer dos gauleses, ou leis sobre leis, como dizia Pontes de Miranda (art. 24, § $4^{\circ}$ ); e

C) possibilitam as leis complementares de normas gerais, em países federativos, a existência de códigos nacionais em matérias administrativas e tributáriás.

A função da leỉ complementar no sistema tributário é objeto de ampla discussão ${ }^{69}$. Não obstante a impossibilidade de adentrar no mérito da presente discussão adota-se, neste traba:hho, o posicionamento de Que são três as funções da lei complementar, em consonância com o texto constitucional e com a chamada corrente "tricotômica". Segundo Coelho (1999), as leis complementares operam dentro do sistema tributário: 1) com função de fazer atuar diretamente dispositivo constituciona/(ex.: art. 148, CF); 2) com função de complementar dispositivos constitucionais de eficácia contida, balizando-thes o alcance (ex.: art. 155, $\S 2^{\circ}$. "a", CF), ou, ainda, 3) com função de integrar dispositivos constitucionais de eficácia limitada, conferindo-thes normatividade plena (ex.: art. 150, Vl, "c", CF). São identificáveis três objetos materiais genéricos da lei complementar tributária segundo o art. 146 da Constituição de 1988: a) dispor sobre conflitos de competência em matéria tributária entre as pessoas políticas. Não haveria conflito de competência propriamente dito, dada a rigidez do sistema de repartição de competências tributárias e sua rigorosa segregação dos impostos privativos e apartados por ordem de governo e taxas e contribuições de melhoria atribuídas com base па precedente competência político-administrativa das pessoas políticas ${ }^{70}$.

Nesse caso, a lei complementar atuaria na Qualidade de lei interpretativa, explicativa e operativa da discriminação das fontes de receitas tributárias, oferecendo critérios ${ }^{71}$, e. evitando o aparente conflito de competência (pois eles são subjetivos e não objetivos).

68 COELHO, Sacha Calmon Navarro. Curso de Direito Tributário Brasileiro. $5^{\text {a }}$ Ed. Rio de laneiro: Forense, 2000, p.119.

59 A partir da análise da Constituição de 1967, duas correntes passaram a disputar espaço no debate acadêmico: 1) a chamada corrente "dicotômica", Que entendia que as leis complementares serviriam unicamente para veicular normas gerais de direito tributário, Que exerceriam duas funçōes: a) dispor sobre conflitos de competência entre as entidades tributantes; b) regułar as limitaçōes constitucionais ao poder de tributar: 11) a corrente chamada "tricotômica", entendendo que haveria três funçôes distintas para a lei complementar: (a) emitir normas gerais de direito tributário; b) dispor sobre conflitos de competência entre a União, os Estados, o Distrito Federal e os Municípios; e c) regular as limitaçöes constitucionais ao poder de tributar.

To Trata:-se-ia, em verdade, de possíveis invasōes de competência em razão da insuficiência intelectiva dos relatos constitucionais pelas pessoas políticas destinatárias das regras de competência relativamente aos fatos geradores de seus tributos. Cada pessoa politica passaria a exercer a tributação de maneira mais ampla Que a prevista na Constituição, causando confíto em área reservada a outra pessoa política.

${ }_{71}$ O Decreto-Lei $406 / 68$ intenta solver possiveis confitos entre o campo de incidência do ICMS e do ISS. 
através de "regras explicativas do discrímine". A lei complementar nessa espécie é regga de atuação direta, não complementando nem contendo dispositivo constitucional, não podendo, alterar o texto constitucional; b) a regulação das limitações constitucionais ao poder de tributar.

Nessa hipótese, o dispositivo constitucional limitador (norma de eficácia limitada) exige complementação Quanto aos requisitos sem os Quais não é possível a fruição da imunidade. A lei complementar nessa espécie é regra de complementação de dispositivos constitucionais de eficácia limitada ou contida, c) editar normas gerais de Direito tributário (art. 24, I. c/c art. 146. III. CF), cujas características são: A) são normas veiculadas pela União, através do Congresso Nacional, mediante leis complementares (lei nacional), Que serão observadas pelas ordens jurídicas parciais, salvo inexistência, euando as ordens parciais poderão suprir a lacuna (art. $24, \S 3^{\circ}$, da CF) até e enQuanto não sobrevenha a solicitada lei complementar, a Qual, se e euando advinda, paralisa as legislações locais, no Que thes for contrária ou incongruente (art. $24, \S 4^{\circ}$, da CF); B) a lei com status de normas gerais de direito tributário, ora em vigor, é o CTN, a teor do art. $34, \S 5^{\circ}$, do ADCT; C) a lei complementar de normas gerais é norma de equalização e unificação do Direito Tributário: D) o art. 146, III, da CF, enumera nominalmente alguns conteúdos de normas gerais, Que são meramente exemplificativos. Conclui Coetho (1999):

[...] o campo de eleição da lei complementar tributária é a norma geral de Direito Tributário [...] O fundamento de validez das normas gerias é a própria Constituição. A seu turno, pelas normas gerais são fornecidos os critérios para a elaboração material das leis tributárias ordinárias federais, estaduais e municipais, sendo, portanto, materialmente, nexos fundantes da validade dessas leis das ordens jurídicas parciais, Que delas só podem prescindir num único caso: inexistência (art. $24, \S 3^{\circ}$, da CF). Mas, tão logo sobrevenha a norma geral, as leis ordinárias em contrário ficam paralisadas, sem eficácia (art. $24, \S 4^{\circ}$, da CF). Retilique-se: no art. $24, \S 4^{\circ}$, onde se lê lei federal, leia-se lei complementar. ${ }^{72}$ (grifo nosso)

As normas gerais veiculadas pelas leis complementares articulam o sistema tributário da Constituição às legislações das pessoas políticas (ordens jurídicas parciais). sendo normas sobre como fazer normas em sede de tributação, e se endereçam aos legisladores das três ordens jurídicas parciais da federação, seus destinatários. Para Torres (200I) a primeira função da lei complementar corresponde ao exercício da competência legislativa tributária da União (legislação federah para a criação de seus tributos originariamente atribuídos na Constituição; nesse caso, não há hierarquia entre a lei complementar e a lei ordinária, porQuanto sua função exaure-se com a instituição do tributo, cessando com o próprio exercício

$\pi$ ldem, ibidem, p. 119. 
da competência. A segunda função corresponde à competência da União para a criação de normas gerais de direito tributário (legislação nacionalih ${ }^{73}$. A hierarquia da lei complementar em relação às leis ordinárias dependerá da funçăo Que ela exerça no sistema. Na função de veículo de normas gerais as leis complementares, porque exercerão função constitutiva de fundamento de validade, formal ou material, sempre terão prevalência sobre QualQuer outra lei, federal, estadual ou municipal, pois estas estarão adstritas ao conteúdo material das normas gerais. O CTN, como norma geral de direito tributário está numa posição, hierarquicamente, superior às demais leis no sistema de fontes do sistema tributário nacional, como se extrai da ilação de Torres (2001):

Lei 5.172/66, enquanto 'lei nacional' Que é, naquilo que for fundamento de validade material para a construção da legislação do 'sistema tributário nacional', terá preeminência sobre todas as demais leis, ordinárias ou complementares, não importa, elaboradas por Qualquer uma das pessoas políticas. [...] na medida Que o art. $34, \S 5^{\circ}$, dos Atos das Disposições Constitucionais Transitórias, Ihe garantiu força de recepção, alçando-a ao patamar funcional de sobrenorma $|\ldots|^{74}$.

${ }_{7}$ Săo as seguintes as funçöes da leỉ complementar como veículo de normas gerais: I) nofmas gerais com funçăo de regular fimitações constitucionais ao poder de tributar, como se verifica no art. 150, VI, "c" ou do art. $195, \S 7^{\circ}$; li) normas gerais com função de evitar conlititos de competência entre as pessoas tributantes, não podendo ofender a repartiçäo constitucional de competências, pertìnente ao federalismo. Esse é o caso de possiveis conflitos entre pessoas políticas distintas (artigos 146, 1 e llt, "a"; 155, §20. XII: e 156, III), entre Estados-membros (ICMS: art. 155, $2^{\circ}$, Xli; ITCMD: art. 155, $\$ 1^{\circ}, 111$ ), ou entre Municípios (ISS: art. $156, \S 3^{\circ}$. 1). Esta hipótese se aplica somente aos impostos previstos na Constituição; III) normas gerais com função de delinir os tributos e suas espécies (art. 146, Ill, "c"). pelo Qual a norma geral deverá aterse aos caracteres gerais, tipificando as características dos tributos, nas suas várias espécies, limitando, nessa hipótese, inclusive a própria União em relação a seus tributos; IV) normas gerais com função de harmonizar os procedimentos de cobrança e liscalização dos tributos, tratando de obrigação, lançamento e crédito tributário (art. 146 , III, "b"; $155, \S 2^{\circ}, \mathrm{XII}$; V) normas gerais com funçăo de uniformizar os prazos de decadência c prescrição; e Vl) normas gerais com função de dar o adequado tratamento ao ato cooperativo (att. 146, IIl, "c").

${ }^{74}$ Ávila (2004), ao lado da função de editar normas gerais, atribui à lei complementar as funçôes de: [1) instituição de tributos especílicos: (art. 148 e art. 1541, da Constituiçäo), casos em que a lei complementar possui "elicácia direta"; III) regulação das limitações ao poder de tributar: (ex.: imunidade do art. 150, Vl, "c", da Constituição), IV) delimitação das regras de competência: trata-se da delimitação do âmbito material de competência, Que empresta às leis complementares duas funções: a) limitar ou restringir o âmbito material de competência, Quando a Constituição o exige (ex.: ITCD: art. 155, § 10; ISS: art. 156, IIl; art. I56, § $3^{\circ}$, II; ICMS: art. $155, \S 2^{\circ}, \mathrm{X}$, "a"; art. 155, $\S 2^{\circ}$, XII; art. $155, \S 2^{\circ}, \mathrm{XII}$, "g"); b) especificação de regras de competência para evitar conflitos de competência: a função da lei complementar, nesse caso, não reside na definiçăo das competências dos entes tributantes, já lixada na Constituição, mas em evitar potenciais conlititos de competência naquelas hipóteses em que o âmbito material da hipótese de incidência repercute na competência de mais de uma pessoa política; $V$ ) tratamento diferenciado e favorecido: funçâo de implementar uma política de diferenciação favorecida para as microempresas e empresas de pequeno porte (introduzido pela Emenda Constitucional $n^{\circ} 42 / 03$ ), imprimindo estabilidade e uniformidade legislativa no Estado Federal. 


\subsection{Proposta de sistematização das hipóteses de conflito}

Da confluência das teorias estudadas, entendemos que a sistematização das hipóteses de conflito deve ser feita a partir da função Que a lei complementar exerce no sistema tributário: Quando esta servir como fundamento de validade da lei ordinária, haverá hierarquiae, conseqüentemente, a natureza do conflito será infraconstitucionale o vício dele resultante a llegalidade; são as hipóteses do art. 146, incisos I e Ill, da Constituição; na hipótese contrária, haverá invasão de competência, e a natureza do conllito será constitucionale o vício dele resultante a inconstitucionalidade, trata-se da hipótese do art. 146, inciso II, da Constituição.

A Constituição inaugura competências específicas num campo material comum (o direito tributário) para a let complementar e para a lei ordinária. Nas hipóteses normativas previstas no artigo 146, incisos I e III, da Constituição, a leì complementar e a lei ordinária estão atuando sob um campo material comum por determinação constitucional; se à primeira (competência constitucional delimitadora) cabe dispor sobre conflitos de competência entre os entes tributantes (inciso l) e estabelecer "normas gerais" para definir os contornos genéricos dos impostos (alínea "a" do inciso III) ${ }^{75}$, definir regras sobre obrigação, lançamento, crédito, prescrição e decadência tributários (alínea "b" do inciso Ill), e para definir o adequado tratamento tributário ao ato cooperativo (alínea " $c$ " do inciso III), é certo que à segunda cabe respeitar esse conteúdo genérico no momento de instituir o tributo $\mathrm{em}$ espécie ou a regra específica (competência constitucional instituidora), na Qual se estabelece relação de subordinação. Relação esta determinada constitucionalmente. A própria Constituição estabeleceu uma relação de hierarouia e subordinação (o destinatário das normas gerais é o legislador ordinário das três ordens jurídicas parciais: União, Estados-membros e Municípios) entre as duas espécies normativas, sendo a lei complementar norma-parâmetro e a lei ordinária norma-objeto.

Cumpre à lei ordinária do ente tributante instituir o imposto em observância ao conteúdo da norma geral; instituir a regra sobre obrigação, lançamento, crédito, prescrição e decadência tributários e dar o adeouado tratamento tributário ao ato cooperativo em observância ao conteúdo da norma geral; instituir o tributo em observância ao critério de resolução do eventual conflito de competência. Tem-se nessas hipóteses de conflito a atribuição de natureza infraconstitucional (conflito entre duas leis - atos infraconstitucionais - Que só, reflexamente, atinge a Constituição), e o vício resultante do conflito é a ilegalidade, sendo que o controle

\footnotetext{
75 Nâo é possível à lei complementar de normas gerais modificar a norma de competência, Que outorgou quais tributos seriam instituídos por cada uma das três ordens jurídicas parciais. Mas como a definição do fato gerador, da base de cálculo e do contribuinte não foi exaurido pelo legislador constituinte, este fixou competência para o legislador complementar esclarecer o conteúdo dos elementos que integram a norma de competência; desse "esclarecimento" nâo pode discrepar o legisiador ordinário da Uniâo, dos Estadosmembros e dos Municípios no momento de instituir o tributo (não há margem de discricionariedade para atuaçăo deste, Que possa ampliar os limites dos conceitos previstos na norma geral).
} 
deve estar na competência jurisdicional do Superior Tribunal de lustiça. Obedecendo às próprias competências fixadas na Constituição, nas situações em que a lei complementar não For o fundamento de validade da lei ordinária, há invasão de competência, Quando esta regular matéria sujeita a ser regulamentada por àQuela. O campo material específico da lei complementar, nesse caso, não é comum ao da lei ordinária, criando-se não uma relação de hierarquia, mas de competência, na Qual a natureza constituciona/do conflito resta presente, e o vício resultante será a inconstitucionalidade. Haverá relação de ofensa direta à Constituição, pois uma espécie normativa teria usurpado competência exclusiva de outra espécie normativa, ferindo a norma constitucional de competência, como no caso do inciso II, do artigo 146, em que a lei complementar é regra de atuação direta. O controle, nesse caso, deve estar na competência jurisdicional do Supremo Tribunal Federal.

Nas hipóteses em que a função da lei complementar for instituir tributo específico (art. 148, art. 153, Vll e art. 154, I) terá atuação direta, nos casos que atuar para resolução de conlitos de competência (art. 155, $\$ 1^{\circ}$, III; art. 155, $\S 2^{\circ}$, XII; art. $156,3^{\circ}$ ) servirá como parâmetro obrigatório (fundamento de validade) para a lei ordinária, assim como no caso do art. 156, HI. Esquematicamente, pode-se sistematizar da seguinte forma as hipóteses de conflito entre a lei ordinária e a lei complementar tributária, prescritas no art. 146 e demais dispositivos da Constituição da República:

\begin{tabular}{|c|c|c|c|c|c|}
\hline Donostiva & 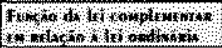 & 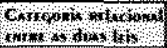 & Fon ods contlio & 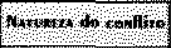 & 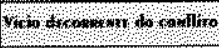 \\
\hline ARE. 146, inciso : & 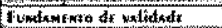 & Hirea egeviar & fwdimkin & Istreixumsirir ucionka! & Nreatistade \\
\hline Avi. 146, tacisa ff & Areagian disats & Compraisecin: & Dimata. & Constimaxitenent & 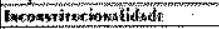 \\
\hline 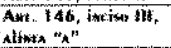 & Fondiasovare do validiadt & Hirakiegeria & Indigerat & Infesconsifich:ional & Hreplidads \\
\hline 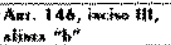 & 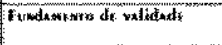 & Wisenanowis & Indizkres & INTharumbrituriamat & Hecinlisadx. \\
\hline 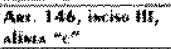 & Fundicmenta da velidads. & Mitsenomotian & Andikfra & 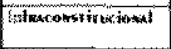 & Hocpalidade \\
\hline Alk: 148 & Azosacio ditasin & Campryincis & Dintzin & Congurvecinmat & 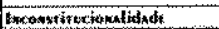 \\
\hline 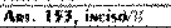 & 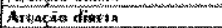 & Comprifincia & Ditatia & Construtcionat & 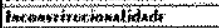 \\
\hline Amx $174, i=6$ soo 1 & Arencite dikrs & Comegrivin & Dintris & Constipticional & 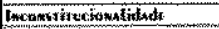 \\
\hline Aw. $135,50^{\circ}, 111$ & 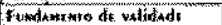 & Hifoasovis & fNdimar:A & 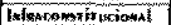 & 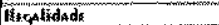 \\
\hline Akr 155, $17^{\circ} \times$. & Fusdenerere de validindr & Hírstangeví & Endintess & I- finscosustiputiona & Etredisdade \\
\hline 156, 111 & 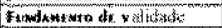 & Ifistageosia & fodtimx 34 & INFAACONSTIYUCIONA: & 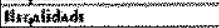 \\
\hline $156,87^{4}$ & 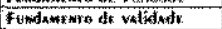 & Hirsedivgetia & fodinesa & 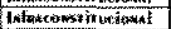 & Busalidads \\
\hline
\end{tabular}

Por fim, se a lei complementar for eleita pelo legislador como espécie normativa para regular matéria a ela não reservada constitucionalmente, concordamos com as conclusões de Celso Bastos e da própria jurisprudência do Supremo Tribunal Federal, segundo o qual terse-á lei complementar materialmente ordinária, e lei ordinária superveniente poderá abrogá-la ou alterá-la, Não se estabelecerá, nesse caso, a hierarquia; é caso de simples revogação ou derrogação. 


\section{CONCLUSÄO}

A análise da jurisprudência dos dois tribunais superiores demonstra não haver critério definidor uniforme da natureza e da consecüência do conflito entre a lei complementar e a lei ordinária, o Que suscita inconstância e casuísmo no uso de diferentes teorias, encerrando um Quadro de insegurança e de ausência de parâmetros seguros para o controle normativo do conflito. No presente trabalho, sustenta-se Que a natureza do conflito entre as duas espécies normativas está relacionada ao papel desempenhado pela lei complementar no sistema constitucional tributário: se esta exercer a função de fundamento de validade da lei ordinária (o Que ocorre nas hipóteses do artigo 146, incisos I e III, da Constituição), então, ter-se-á, Que a natureza do conflito será infracontitucional, e o vício decorrente do conflito é a ilegalidade, pois as duas espécies normativas estarão numa relação de hierarœuia, e atuando sobre um âmbito material comum.

Caso contrário, se a lei complementar tiver atuação direta, isto é, não servir como fundamento de validade da lei ordinária, a hipótese de conflito normativo entre ambas possui natureza constitucional e se resolve em vício de inconstitucionalidade, pois se trata de invasão de competência legislativa (as espécies normativas estão atuando sobre âmbitos materiais nã̉o comuns) e não de hierarquia (o Que ocorre na hipótese do artigo [46, inciso II). A mesma sistematização aplica-se às demais hipóteses em que o texto constitucional exige, explicitamente. a lei complementar como espécie normativa para regular matérias tributárias. As bases para a solução do conflito estão na conjunção das teorias da hierarquia e da invasão de competência legislativa com as próprias competências estatuídas pela Constituição, Que funda relações de subordinação ou de coordenação entre diferentes normas primárias de seu sistema de processo legislativo. O artigo 146 da Constituição deve ser interpretado em estrita conexão sistemática com o artigo $24, \S 1^{\circ}$, como forma de preservar o sistema federativo.

De outra parte, não há como negar a importância da teoria da inconstitucionalidade reflexa para a resolução do conflito como suporte de uma consistente teoria da inconstitucionalidade, Que preserva o núcleo essencial do conceito e afasta as hipóteses indiretas de ofensa ao texto constitucional. Decorre disso, Que, a priori, o conflito entre duas espécies normativas primárias, contidas no sistema de processo legislativo (fontes formais de criação do direito) da Constituição deve ser controlável infraconstitucionalmente (lei complementar: norma-parâmetro e lei ordinária: norma-objeto) e a não ser nos casos em Que a ofensa se der diretamente ao texto da lei fundamental. 


\section{REFERÊNCIAS BIBLIOGRÁFICAS}

ALVIM, Eduardo Arruda. Lei Complementar Tributária. Cadernos de Direito Constitucional e Ciência Política, São Paulo, n. 06, p. 47-70, 1994.

AMARO, Luciano. Direito Tributário Brasileiro. $7^{\text {a }}$ Ed. São Paulo: Saraiva, 2001.

ATALIBA, Geraldo. Regime Constitucional e Leis Nacionais e Federais. Revista de Direito Público, São Paulo, n. 53-76.

ÁVILA, Humberto. Sistema Constitucional Tributário. São Paulo: Saraiva, 2004. 60l p.

BALEEIRO, Aliomar; DERZI, Misabel Abreu Machado (Atual.). Limitações Constitucionais ao Poder de Tributar. $7^{a}$ Ed. Rio de Janeiro: Forense, 1999, 859 p.

BASTOS, Celso. A Inexistência de Hierarquia entre a Lei Complementar e as Leis Ordinárias. Cadernos de Direito Tributário e Finanças Públicas, São Paulo, n. 26, p. 10-20, 1999.

Bastos Editor, 1999. - Lei Complementar - Teoria e Comentários. São Paulo: Celso

- Do Estudo da Inconstitucionalidade no Campo Específico da Lei Complementar. Revista de Direito Constitucional e Internacional, São Paulo, n. 37, p. 5563,2001 .

BARROSO Luis Roberto. O Controle de Constitucionalidade no Direito Brasileiro. São Paulo: Saraiva, 2004.

. Temas de Direito Constítucional. Tomo III. Rio de Janeiro: Renovar, 2005.

BATALHA, Célio de Freitas. Lei Complementar em Matéria Tributária. Revista de Direito Tributário, São Paulo, n. 49, p.121-129, 1991.

BESTER, Gisela Maria. Direito Constitucional, volume I: Fundamentos Teóricos. São Paúlo: Manole, 2005.

BITENCOURT, Lúcio. O Controle Jurisdicional da Constitucionalidade das Leis. Rio de Janeiro; Forense, 1968.

BORGES, José Souto Maior. Eficácia e Hierarquia da Lei Complementar. Revista de Direito Público, São Paulo, n. 25, p. 93-103, 197.3.

$$
\text { - Lei Complementar Tributária. São Paulo: RT, } 1975 .
$$

CALMON, Eliana. O Superior Tribunal de Justiça na Constituição. Revista de Estudos Tributários, Porto Alegre, n. 16, p.1-10; 2000.

CANTO, Gilberto de Ulhôa. Lei Complementar Tributária. Cadernos de Pesquisa Tributária. São Paulo: Resenha Tributária. 1990

CARRAZZA, Roque Antonio. Curso de Dircito Constitucional Tributário. 5a Ed. São Paulo: Malheiros, 1993.

CASSONE, Vitorio. Direito Tributário: fundamentos constitucionais da tributação, classificação dos tributos, interpretação da legis slação tributária, doutrina, prática e jurisprudência. São Paulo: Atlas; 2004.

CARVALHO, Paulo de Barros. Curso de Direito Tributário. I5a Ed. São Paulo: Saraiva, 2003.

CLÉVE, Clèmerson Merlin. A Fiscalização Abstrata de Constitucionalidade no Direito Brasileiro. 2a Ed. São Paulo: RT, 2000, 484 p.

COELHO, Sacha Calmon Navarro. A Lei Complementar como Agente Normativo Ordenador do Sistema Tributário e da Repartição de Competências Tributárias. $8^{\circ}$ Simpósio Nacional IOB de Direito Tributário, São Paulo, p. 135-149, 1999.

DIFINI, Luiz Felipe Silveira. Manual de Direito Tributário. São Paulo: Saraiva, 2003.

ESTEVES, Maria do Rosário. Normas Gerais de Direito Tributário. São Paulo: Max Limonad, 1997 
FILHO, Manoel Gonçalves Ferreira. Do Processo Legislativo. 3a Ed, São Paulo: Saraiva, 1995. $2003.371 \mathrm{p}$. . Curso de Direito Constitucional. 30 Ed. São Paulo: Saraiva.

MACHADO, Hugo de Brito. Posição Hierárquica da Lei Complementar. Revista Dialética de Direito Tributário, São Paulo, n. 14, p. 19-22, 1996.

MARTINS, Ives Gandra da Silva. Sistema Tributário na Constituiç̧ão de 1988. Săo Paulo: Saraiva, 1989.

MENDES, Gilmar Ferreira. Jurisdição Constitucional. O Controle Abstrato de Normas no Brasil e na Alemanha, 3a Ed. São Paulo: Saraiva, 1999, 375 p. - MARTINS, Ives Gandra da Silva. Controle Concentrado de Constitucionalidade. Comentários à Lei 9.868, de 10 l [-1999. São Paulo: Saraiva, 2001.

MIRANDA, lorge. Teoria do Estado e da Constituição. Rio de laneiro: Forense, 2002,546 P.

MORAES, Alexandre. Direto Constitucional. 10ª Ed. São Paulo: Atłas, 2001. infraconstitucional. São Paulo: Atlas, 2002.

Constituição do Brasil interpretada e legislação

NETTO, André Luiz Borges. Fontes de Direito Tributário. Previsão Constitucional. Lei Complementar. Cadernos de Direito Constitucional e Ciência Política, São Paulo, n. 15, p. 128-J48,1996.

NEVES, Marcelo. Teoria da Inconstitucionalidade das Leis. São Paulo: Saraiva, $1988,177 \mathrm{p}$.

PALU, Oswaldo Luiz. Controle de Constitucionalidade. Conceitos, sistemas e efeitos. 2a Ed. São Paulo: RT, 2001.

PARGENDLER, Ari. O Recurso Especiał e o Código Tributário Nacional. ST): Dez Anos a Serviço da justiça: Doutrina - ed. comemorativa. Brasilia: Superior Tribunal de lustiça, 1999 .

PAUSEN, Leandro. Direito Tributário. Constituição e Código Tributário à luz da Doutrina e da Jurisprudência, $7^{\mathrm{a}} \mathrm{Ed}$. Porto Alegre: Do Advogado, 2005.

PIZOLIO IÚNIOR, Reinaldo. Considerações acerca da lei complementar em matéria tributária. Cadernos de direito tributário e finanças públicas, n. 14, p. 173-206, jan./mar. 1996.

POLETII, Ronaldo. Controle da Constitucionalidade das Leís. 2a Ed. Rio de Janeiro: Forense, 2001.

RAMOS, Elival da Silva. A Inconstitucionalidade das leis: vício e sanção. São Paulo: Saraiva, 1994

RIZZINI, Antonio Ferreira. Leis Complementares. Aspectos de sua aplicabilidade. Cadernos de Direito Consțtitucional e Ciência Política, São Paulo, n.13, p.138-144, 1995.

TAVARES, André Ramos. Perfil Constitucional do Recurso Extraordinário. In: TAVARES, André Ramos (Org.). Aspectos Atuais do Controle de Constitucionalidade no Brasil. Rio de laneiro: Forense, 2003, p. 3-60.

- Curso de Direito Constitucional. 2a Ed. São Paulo: Saraina, 2003. 1033 p.

TEMER, Michel. Elementos de Direito Constitucional. 9a Ed. São Paulo: Malheiros, 1992.

TORRES, Heleno Taveira. Código Tributário Nacional: Teoria da Codificação, Funções das Leis Complementares e Posição Hierárquica no Sistema. Revista Dialética de Direito Tributário, São Paulo, n. 71, p. 84-103, 2001.

XAVIER, Alberto. Tipicidade da Tributação, Simulação e Norma Antielisiva. São Paulo: Dialética, 2002. 